\title{
Green Way of Biomedicine - How to Force Plants to Produce New Important Proteins
}

\author{
Aneta Wiktorek-Smagur1, Katarzyna Hnatuszko-Konka², Aneta Gerszberg2, \\ Tomasz Kowalczyk ${ }^{2}$, Piotr Luchniak ${ }^{2}$ and Andrzej K. Kononowicz ${ }^{2}$ \\ ${ }^{1}$ Nofer Institute of Occupational Medicine \\ ${ }^{2}$ Department of Genetics Plant Molecular Biology and \\ Biotechnology University of Lodz \\ Poland
}

\section{Introduction}

Recombinant proteins can be expressed in transformed cell cultures of bacteria, yeasts, molds, mammals, plants, insects, or via transgenic plants and animals. Numerous factors influence quality, functionality, yield and protein production rate, so the choice of appropriate expression system is of primary importance. During last few years, plants have become an increasingly promising and attractive platform for recombinant protein production (Basaran \& Rodriguez-Cerezo, 2008). Progress in recombinant DNA technology, plant transformation and in vitro regeneration techniques are major reasons why plants have emerged as efficient expression systems. Plant expression systems offer significant advantages over the other expression systems (Table 1). First of all, plants have a higher eukaryote protein synthesis pathway very similar to animal cells with only minor differences in protein glycosylation. Therefore, plant biosynthesis pathway ensures correct structure even in the case of highly complex proteins. In contrast to plants, bacteria are not able to carry out most of posttranslational modifications essential for eukaryotic proteins activity. There is no risk of contamination of recombinant proteins with human or animal pathogens (HIV, hepatitis viruses, prions), bacteria endotoxins or oncogenic DNA sequences (Sharma \& Sharma, 2009).

Other advantages of the plant-based expression systems include: high scalability (in the case of field cultivation), low production cost of biomass (agriculture), in some cases low upstream costs (edible vaccines, purification process can be omitted), and what is most important - the ability to produce target proteins with desired structures and biological functions (Boehm, 2007). Recombinant proteins expressed in plants can be accumulated to a high level in seed endosperm, fruit or storage organs (e.g. tubers, roots) or secreted directly to the culture media. Because plant culture media contain no exogenous proteins, the recovery of recombinant proteins from a medium is expected to be much simpler and less expensive than the recovery from homogenized biomass (Cox et al., 2009). 


\begin{tabular}{lllllll}
\hline Features & $\begin{array}{l}\text { Transgenic } \\
\text { plants }\end{array}$ & $\begin{array}{l}\text { Plants } \\
\text { viruses }\end{array}$ & Yeast & Bacteria & $\begin{array}{l}\text { Mammalian } \\
\text { cell culture }\end{array}$ & $\begin{array}{l}\text { Transgenic } \\
\text { animals }\end{array}$ \\
\hline Cost/storage & Cheap & Cheap & Cheap & Cheap & Expensive & Expensive \\
\hline Distribution & Easy & Easy & Feasible & Feasible & Difficult & Difficult \\
\hline Gene size & Not limited & Limited & Unknown & Unknown & Limited & Limited \\
\hline Glycosylation & Correct & Correct & Incorrect & Absent & Correct & Correct \\
\hline Production costs & Low & Low & Medium & Medium & High & High \\
\hline Production scale & Worldwide & Worldwide & Limited & Limited & Limited & Limited \\
\hline Propagation & Easy & Feasible & Easy & Easy & Hard & Feasible \\
\hline $\begin{array}{l}\text { Protein folding } \\
\text { accuracy }\end{array}$ & High & High & Medium & Low & High & High \\
\hline $\begin{array}{l}\text { Protein } \\
\text { homogeneity }\end{array}$ & High & Medium & Medium & Low & Medium & Low \\
\hline Protein yield & High & Very high & High & Medium & Medium-high & High \\
\hline Safety & High & High & Unknown & Low & Medium & High \\
\hline \begin{tabular}{l} 
Scale up costs \\
\hline Therapeutic risk
\end{tabular} & Unknown & Low & High & High & High & High \\
\hline Time required & Medium & Low & Medium & Low & High & High \\
\hline
\end{tabular}

Table 1. Comparison of features of recombinant protein production in existing systems (according to Fischer and Emans 2004; worked out / modified on the basis of Demain and Vaishnav 2009).

The usage of aquatic plants e.g. Lemnaceae seems to be a good solution. For example Rival et al. (2008) made studies on obtaining aprotinin from Spirodela oligorrhiza (duckweed). Their experiments show that significant amounts of recombinant aprotinin can be produced using Spirodela as a plant host. Whereas Cox and co-workers (2009) expressed human monoclonal antibody (mAbs) in Lemna minor. The micro-alga Chlamydomonas reinhardtii has recently been shown as a promising platform for foreign protein production (Muto et al., 2009). This photosynthetic single-celled plant possesses several interesting features in comparison to the majority of plants as it has a rapid doubling time (ca. $10 \mathrm{~h}$ ); its homogenous culture is easily scaled up; it has a rapid sexual cycle (ca. 2 weeks) with stable and viable haploids. All these attributes make the time of petting a final product on a large-scale much shorter in comparison to higher plants (months or years). Growth in containment bioreactors allows to control conditions of farming as well as reduces the risk of contamination and loss of algae due to pathogens. It is worth mentioning that all three genomes of C. reinhardtii have been fully sequenced affording strong foundation for targeted genetic manipulation (Specht et al., 2010). 
Feasible storage of recombinant proteins in desiccated plant parts excludes the requirement for its immediate isolation and lowers the risk of the loss of biological function during prolonged freezing of preparations. For example, antibodies or vaccines expressed in cereal seeds remain stable at ambient temperatures for years (Stoger et al., 2002). Until recently, low accumulation levels have been the major bottleneck for plant-made recombinant protein production. However, several breakthroughs have been done during past few years allowing for high accumulation levels. Mainly through chloroplast, vacuole, ER lumen transient expression, coupled with subcellular targeting and protein fusions (Sharma and Sharma, 2009). Viral transfection and agroinfiltration are promising alternative strategies ensuring increase in yields and speeding up the development of an expression platform (Gleba et al., 2005). On the other hand, plant-based expression systems are different from the mammalian host pattern of glycosylation. The occurrence has raised concerns regarding the potential immunogenicity of plant-specific complex N-glycans ( a 1,3-fucose and $\beta$ 1,2xylose residue), which are present in the heavy chains of plant-derived antibodies (Gomord and Faye 2004). The above mentioned residues have been confirmed not only to induce immune response but also to make foreign proteins undergo a conformational change making them different from the native ones which results in decrease in their biological activity. However, some achievements in humanized glycosylation or removal of enzymatic pathway generating immunogenic residues on glycoproteins have been reported. Recently it has been shown that glycoengineered moss (Physcomitrella patens) can synthesize proteins carrying a humanized glycosylation pattern (Decker and Reski, 2008). A few years ago Physcomitrella patens platform was developed and commercialized as a contained tissue culture system for recombinant protein production in photo-bioreactors [Biotech $\mathrm{GmbH}$ (@) greenovation)]. P. patens has some characteristic features which make it a suitable system for foreign protein production. Firstly, it grows rapidly under photoautotrophic conditions and secondly the moss protonema can release the desired protein into the medium. The moss remains productive in the system for a period of six months, in contrast to animal cell cultures (20 days) (Decker and Reski, 2008).

Other approaches to overcome undesirable glycosylation accommodate export of foreign proteins into subcellular compartments: ER lumen, where glycosylation characteristic of plants does not take place; cytosol, where glycosylation process is not found; or recombinant protein expression export into plastids (proteins do not undergo glycosylation there). According to several studies ER targeting gives higher yield of biologically active protein than cytosol targeting (referred by Boehm, 2007).

Potential disadvantages of transgenic plants include possible contamination with pesticides, herbicides, and toxic plant metabolites. Proteolytic degradation, post/transcriptional gene silencing, position effect and transgenic recombination are other obstacles affecting stability or expression level of transgenic plants (Basaran and Rodriguez-Cerezo, 2008).

The public concern about health and environmental risk associated with transgenic plants is being considered at different levels: inherent risk of transgene leakage into non-transgene crops or naturally occurring wild type species (transgene escape through pollen); transgene spread by seed or fruit dispersal; horizontal gene transfer by asexual means; unintentional exposure of non-targeted organisms (e.g. birds, insects or soil microorganism); elicitation of allergic response/reaction in people (Basaran and Rodriguez-Cerezo, 2008). There are some strategies which allow to alleviate these problems including usage of closed culture 
facilities, such as greenhouses, hydroponic or suspension bioreactors or plastid transformation (as plastids are inherited through maternal tissues in most species and the pollen does not contain chloroplasts, hence the transgene cannot be transferred) (Basaran and Rodriguez-Cerezo, 2008).

From economical point of view, plants can be an alternative system for recombinant protein production (especially biopharmaceutical) in comparison to those exploiting mammalian or bacterial cell cultures. In this system a desired foreign protein can be produced at $2-10 \%$ of the cost of microbial fermentation system and at $0.1 \%$ of mammalian cell cultures, although it depends on the protein of interest, product field and a plant used. In general, the recombinant protein yields up to $1.5 \%$ of the total soluble protein (TSP). For example the content of antibodies does not exceed $0.35 \%-2 \%$ and vaccines- $0.01-$ $0.4 \%$ of TSP (Basaran and Rodriguez-Cerezo, 2008). On the other hand, phytase from A. niger was obtained at the level $14 \%$ of the total tobacco soluble protein, but hirudin from $H$. medicinalis at $1 \%$ of canola seed weight and GUS from E. coli was produced in corn at $0.7 \%$ of TSP (Demain and Vaishnav 2009).

\section{Expression strategies}

Gene expression and synthesis of proteins is a complex multi-step process. For efficient expression of recombinant proteins in plants, it is essential to optimize every step of the process for the plant machinery. This includes the methods of plant transformation, the choice of a transgene promoter, improvement of transcript stability and the efficiency of its translation. After translation, the protein needs to be accumulated in plant cells or effectively secreted.

\subsection{Stable nuclear transformation}

The first step in plant transformation consists in the entrance of a desired genomic sequence into a plant cell. Stable nuclear transformation is caused by integration of the recombinant DNA in the nuclear genome. DNA can be transferred into the nuclear genome by either direct (e.g. biolistics) or indirect (e.g. Agrobacterium) methods, it depends on the plant species and the type of tissue (Thanavala et al., 2006).

In the stable nuclear transformation whole plants can be regenerated, eventually producing a seed stock or a plant tissue maintained in an aseptic culture. The advantage of this system is that the transgene is heritable, permitting the establishment of a seed stock for future use. Establishment and characterization of stable transgenic lines can be costly and time consuming. Large numbers of transgenic lines need to be screened and analyzed before a single optimal line can be selected for protein production (Ling et al., 2010). Other disadvantages are gene silencing and position effects.

Nuclear transformation has been employed and extensively studied in many plant species, however, it generally results in low expression of soluble foreign proteins (Yap \& Smith, 2010).

Recombinant proteins can be targeted to different subcellular compartments in plant cells, such as cytostol, apoplast, endoplasmic reticulum, vacuole or chloroplast. 


\subsection{Transplastomics}

Using particle bombardment or polyethylene glycol (PEG) treatment, DNA can be targeted into the chloroplast genome (Yusibov \& Rabindran, 2008). Each cell contains a large number of plastids, $\sim 100$ chloroplasts per cell, and each of them contains about 100 genomes. Transplastomic lines vs. nuclear ones have significantly greater yield of foreign proteins (1-20\% TSP) due to the high number of copies of the chloroplast genome and they offer major advantage in terms of transgene containment, as chloroplast genomes are predominantly maternally inherited, limiting out-crossing of the transgenic pollen. No transcriptional or posttranscriptional silencing effects have been observed in chloroplast transformation (Yap \& Smith, 2010). Chloroplasts also support operon based on transgene allowing the expression of multiple proteins from a single transcript. There are two disadvantages of the chloroplast system - first: chloroplast transformation is not a standard procedure and is thus far limited to a relatively small number of crops, second: lack of some of the eukaryotic machinery for posttranslational modification (Yusibov \& Rabindran, 2008).

Gene integration in the plastid genome occurs by means of two homologous recombinant events mediated by a bacterial-like Rec A based system. Vectors include two 'targeting' regions flanking the selectable marker gene and a cloning site for insertion of the gene of interest. The targeting regions are between 1 and $2 \mathrm{~kb}$ in size and are plastid DNA sequences able to direct transgenic integration into plastome intergenic regions. Integration by homologues recombination in a preselected genome region enables insertion of only transgenic sequences and prevents uncontrollable variation in the expression of transgene. Strong promoters for plastid encoded polymerase (PEP) from the $r r n$ operon and the $p s b A$ gene are used. Rregulatory sequences at the $5^{\prime}$-terminus must include a $5^{\prime}$ untranslated region (UTR). Plastid transgene expression can be also achieved with the use of the T7 phage promoter and nuclear-encoded, plastid imported T7 RNA polymerase. In some cases protein accumulation was enhanced by translational fusion of a plastid gene $\mathrm{N}$ terminal sequence with the protein of interest by including sequences downstream of the ATG start codon (downstream box) in the transgene 5 'cassette that resulted in improved translation and/or protein stability. The 3'cassettes derived from 3'UTR of plastid genes generally function as inefficient terminators of transcription, but are important for plastid transcripts stability (Cardi et al., 2010).

\subsection{Optimization of expression level}

Increasing the transcription rate of stably transformed gene sequences is the most direct and efficient approach to increase protein expression. This is mainly achieved with the use of a strong constitutive or inducible promoter. Constitutive promoters directly drive the expression in all plant tissues and are independent of the production host developmental stage. The best known and most widely used constitutive promoter in plant biotechnology is derived from Cauliflower Mosaic Virus (CAMV35S). It is more effective in dicots than monocots. Alternative constitutive promoters frequently used in plant cell transformation are the ubiquitin promoter, histone $H 2 B$ promoter and the (ocs) 3 mas promoter (Hellwig et al., 2004). The ubiquitin promoter, isolated from a variety of plants including maize, Arabidopsis, potato, sunflower, tobacco and rice, has been frequently used to express biopharmaceuticals in plant cells. The (ocs)3mas promoter, constructed from octopine synthase (osc) and 
mannopine synthetase (mas) agrobacterial promoter sequences, was used for the expression of Hepatitis B antigen in a soybean cell culture (Smith et al., 2002). Other constitutive promoters used for expression of foreign genes in transgenic plants include: tobacco cryptic constitutive promoter (Menassa et al., 2004), Mac promoter which is a hybrid mannopine synthetase promoter and cauliflower mosaic virus 35S promoter enhancer region (Dai et al., 2000), rice actin promoter (Huang et al., 2006), banana actin promoter (Herman et al., 2001), C1 promoter of cotton leaf curl Multan virus (Xie et al., 2003), nopaline synthase promoter (Stefanov et al., 1991).

Inducible promoters allow external regulation by chemical stimuli such as alcohol, steroids, salts, sucrose or environmental factors such as temperature, light, oxidative stress and wounding. Inducible expression is advantageous as this allows protein production to be separated from cell growth. The use of chemical inducible promoters in combination with the chemical responsive transcription factor can further restrict the target transgene expression to specific organs, tissues or even cell types (Zuo \& Chua, 2000). The examples of inducible promoters and synthetic transcription activators are: the rice a-amylase 3D $(R A m y 3 D)$ promoter, which is induced by sucrose starvation; the oxidative stress-inducible a peroxidase (SWAPA2); an estradiol-inducible chimeric XVE transcription activator and dexamethasone-inducible $\mathrm{pOp} / 4 \mathrm{v}$ transcription activator ( $\mathrm{Xu}$ et al., 2011), hydroxyl-3methylglutaryl CoA reductase 2 promoter, which is inducible by mechanical stress (Cramer et al., 1996).

Tissue-specific promoters control gene expression in a tissue or in a developmental stage specific way. The transgen driven by such a promoter is expressed in a specific tissue leaving all the other tissues unaffected. It helps to force transgene expression in storage organs like seeds, tubers or fruits. Several of such promoters were tested: tuber specific patatin promoter (Jefferson et al., 1990), fruit specific E8 promoter (Jiang et al., 2007), arcelin promoter (Osborn et al., 1988), maize globulin 1 promoter (Rusell \& Fromm, 1997), 7s globulin promoter (Fogher, 2000), rice glutelin promoter (Wu et al., 1988) and soybean Pconglycinin subunit promoter (Chen et al., 1986).

The optimization of promoters activity can be further improved by means of engineered DNA elements - enhancers, activators or repressors located up or downstream of the core promoter. Enhancers are shown to increase gene expression when placed proximally to the promoter, they bind activator proteins and promote RNA polymerase II placement at the TATA box. Transcription is also enhanced with flanking the transgene by nuclear scaffold/matrix attachment regions (S/MARs) important for structural organization of eukaryotic chromatin (Halweg et al., 2005).

The translational efficiency of a transgene is determined by proper processing (capping, splicing, polyadenylation, nuclear export) and mRNA stability. The $5^{\prime}$ and $3^{\prime}$ untranslated region (UTR) of the plant mRNA plays crucial roles in its processing (Cowen et al., 2007). The $5^{\prime}$-UTR is very important for $5^{\prime}$ capping and enables translation initiation, the $3^{\prime}$-UTR is indispensable in transcript polyadenylation which in turn influences the stability of mRNA (Chan and $\mathrm{Yu}, 1998$ ). These untranslated sequences can be manipulated for the optimization of protein expression.

As the protein is synthesized, it undergoes several modifications before final delivery to its cellular destination. These modifications include enzyme involving glycosylation, 
phosphorylation, methylation, ADP-ribosylation, oxidation, acylation, proteolytic cleavage and non-enzymatic modifications like deamidation, glycation, racemization and spontaneous changes in protein conformation (Gomord \& Faye, 2004). Post-translational proteolysis can be effectively minimized by targeting the foreign proteins to sub-cellular compartments such as the endoplasmic reticulum (ER). Proteolysis is more likely to occur in the apoplast and cytosol. ER retrieval signal (e.g. KDEL, HDEL) retains the expressed protein in the ER lumen and has been used to improve foreign protein stability. The ER contains many molecular chaperones facilitating nascent proteins folding or assembly and it is regarded as an ideal compartment for accumulating many classes of foreign proteins (Nuttal et al., 2002).

Other strategies for proteolytic degradation reduction are: co-expression of recombinant protein and protease inhibitors, co-expression of protein co-factors or subunits, knockout mutations in the genes encoding specific proteolytic enzymes.

The recent advent of highly efficient transient expression systems has completely changed the concept and revolutionized plant made pharmaceutical research. Transient transformation implies the expression of foreign DNA which cannot be inherited but is still transcribed within the host cell in a transient manner. Transient gene expression provides a rapid alternative to the time consuming stable transformation methods. This approach uses the plant hosts - Arabidopsis thaliana, Nicotiana tabacum, Nicotiana benthamina, Lactuca sativa. Transient expression of recombinant proteins in plants is performed by the use of engineered plant viruses and/or Agrobacterium mediated DNA transfer (agroinfection/agroinfiltration). Fast and high level expression is the major advantage of the transient expression systems. Full expression of a gene of interest in agroinjected leaves may be achieved in 3-4 days after infiltration with Agrobacteria. This system is simple and experimental procedures do not require expensive supplies and equipment. Leaves of greenhouse grown plants are infiltrated using a syringe without a needle, vacuum infiltration or the wound and agrospray inoculation method (Medrano et al., 2009). Supplementation of the infiltration media with Silwet L-77, Tween-20, or Triton X-100 improves the efficiency of transformation. In the transient expression system one can use different virus types: Tobamoviruses, Potexviruses, Potyviruses, Bromoviruses, Comoviruses and Gemniviruses. Prolific production of any given protein using the plant virus approach results from the fact that a virus can infect a plant systemically by moving in its symplast. The Agrobacterium based method involves the injection or vacuum infiltration of whole plants or their parts with a suspension of bacteria harboring the construct of interest (Gómez et al., 2009). Agrobacterium delivered plant viral vectors use the RNA polymerase II mediated nuclear export route including $5^{\prime}$ end capping, splicing and $3^{\prime}$ end formation. Plant RNA viruses replicate in the cytoplasm and are not adapted to nuclear splicing machinery which recognizes and removes cryptic introns from viral RNA leading to its degradation. The Agrobacterium delivered so called 'first generation' TMV and PVX vectors have low production capacity and require coinjection of a plasmid encoding gene silencing suppressor such as tombusvirus p19 or potyvirus P1/HC-Pro (Komarova et al., 2010).

A major breakthrough in viral expression strategies was facilitated by the recent advent of deconstructed virus vectors. Originally reported for the TMV-based magnICON system developed by ICON Genetics $\mathrm{GmbH}$ merges advantages of Agrobacterium-mediated DNA 
delivery and upgraded TMV based vectors where putative cryptic splice sites were removed and multiple plant introns inserted. Thus the basic idea is to amplify the foreign gene delivered by Agrobacterium tumefaciens to multiple areas of the plant allowing the virus to replicate and spread. In this process, bacteria start initial infection delivering the T-DNA encoded viral replicon to the nuclei of a large number of cells. Then, the transcripts are transported to the cytoplasm where the viral RNA amplification renders high yields of the desired protein (Gleba et al., 2005).

In conclusion, the two major strategies for expressing proteins in whole plants are transient expression with viral vectors and stable transformation where transgenes are targeted to either the nuclear or chloroplast genome. Stable transformation offers the advantage that protein production is scalable to large field production methods. However, this can be offset by low expression levels and the long time required for creating expressor lines stable across multiple generations. Today's most promising direction in the referred field is emerging from synthesis of genetically engineered agrobacteria, viruses and plants in one precisely tailored system where synthetic and system biology meet each other.

\section{Overview of plant-derived medical recombinant proteins}

\subsection{Plant derived antibodies}

Over the last few decades, medical biotechnology has led to major advances in diagnosis and therapy. At present most diseases can be detected at an early stage, and their treatment is more specific and potent. Biotechnological methods allow to identify the molecular mechanisms of a disease facilitating development of new diagnostic techniques and speeding up development of novel molecularly targeted drugs. One of the therapeutic strategies in the treatment of many diseases is the use of antibodies. Antibodies are a class of topographically homologous multidomain glycoproteins produced by the immune system and they display a remarkably diverse range of binding specificities. Since the first production of monoclonal antibodies by Kohler and Milstein in 1975 they have become an extremely important and valuable tool in medicine (Yarmush et al., 2003).

Constantly increasing demand for new and safe monoclonal antibodies forces development of high-performance production systems. Since the first report on antibody production in N. tabacum plants (Hiatt et al., 1989), plantibodies have been produced in various plant systems (Table 2).

\begin{tabular}{lllllll}
\hline Product & Disease/Pathogen & Plant & Promoter & $\begin{array}{l}\text { Expression } \\
\text { level }\end{array}$ & Organ & Reference \\
\hline $\begin{array}{l}\text { Human anti- } \\
\text { rabies } \\
\text { monoclonal } \\
\text { antibody }\end{array}$ & Rabies & Tobacco & $\begin{array}{l}\text { CaMV 35S } \\
\text { promoter with } \\
\text { duplicated } \\
\text { upstream B } \\
\text { domains }\end{array}$ & $0.07 \%$ TSP & Leaves & $\begin{array}{l}\text { Ko et al., } \\
2003\end{array}$ \\
\hline $\begin{array}{l}\text { Human } \\
\text { monoclonal } \\
\text { antibody }\end{array}$ & Hepatitis-B virus & Tobacco & $\begin{array}{l}\text { CaMV 35S } \\
\text { promoter with } \\
\text { the omega } \\
\text { sequence }\end{array}$ & $\begin{array}{l}0.2-0.6 \% \\
\text { TSP }\end{array}$ & $\begin{array}{l}\text { Suspension Yano et al., } \\
\text { cell cultures 2004 }\end{array}$ \\
\hline
\end{tabular}




\begin{tabular}{|c|c|c|c|c|c|c|}
\hline Product & Disease/Pathogen & Plant & Promoter & $\begin{array}{l}\text { Expression } \\
\text { level }\end{array}$ & Organ & Reference \\
\hline $\begin{array}{l}\text { Full-length } \\
\text { monoclonal } \\
\text { mouse IgG1 } \\
\text { (MGR48) } \\
\end{array}$ & - & Tobacco & $\begin{array}{l}\text { CaMV 35S, TR2' } \\
\text { promotor }\end{array}$ & $\begin{array}{l}30-60 \mathrm{mg} \text { of } \\
\text { fresh weight }\end{array}$ & Leaves & $\begin{array}{l}\text { Stevens et } \\
\text { al., } 2000\end{array}$ \\
\hline $\begin{array}{l}\text { Human- } \\
\text { derived, } \\
\text { monoclonal } \\
\text { antibody } \\
\end{array}$ & Anthrax & Tobacco & CaMV35S & - & Leaves & $\begin{array}{l}\text { Hull et al., } \\
2005\end{array}$ \\
\hline $\begin{array}{l}\text { Anti- } \\
\text { Salmonella } \\
\text { enterica } \\
\text { single-chain } \\
\text { variable } \\
\text { fragment } \\
\text { (scFv) } \\
\text { antibody }\end{array}$ & Salmonella enterica & Tobacco & $\begin{array}{l}\text { EntCUP4, single } \\
\text { and double- } \\
\text { enhancer } \\
\text { versions CaMV } \\
35 S\end{array}$ & $\begin{array}{l}41.7 \mathrm{ug} \text { of } \\
\mathrm{scFv} / \mathrm{g} \text { leaf } \\
\text { tissue }\end{array}$ & Leaves & $\begin{array}{l}\text { Makvandi- } \\
\text { Nejad et al., } \\
2005\end{array}$ \\
\hline $\begin{array}{l}\text { Human anti- } \\
\text { rabies virus } \\
\text { monoclonal } \\
\text { antibody }\end{array}$ & Rabies & Tobacco & $\begin{array}{l}\text { CaMV 35S with } \\
\text { duplicated } \\
\text { upstream B } \\
\text { domains (Ca2p), } \\
\text { (Pin2p) }\end{array}$ & $\begin{array}{l}30 \mathrm{ug} / \mathrm{g} \text { of } \\
\text { cell dry } \\
\text { weight }\end{array}$ & $\begin{array}{l}\text { Cell } \\
\text { suspension } \\
\text { culture }\end{array}$ & $\begin{array}{l}\text { Girard et } \\
\text { al., } 2006\end{array}$ \\
\hline $\begin{array}{l}\text { BoNT } \\
\text { antidotes }\end{array}$ & $\begin{array}{l}\text { Botulinum } \\
\text { neurotoxins } \\
\text { (BoNTs) }\end{array}$ & Tobacco & CaMV35S & $\begin{array}{l}20-40 \\
\mathrm{mg} / \mathrm{kg}\end{array}$ & Leaves & $\begin{array}{l}\text { Almquist et } \\
\text { al., } 2006\end{array}$ \\
\hline $\begin{array}{l}\text { TheraCIM } \\
\text { recombinant } \\
\text { humanized } \\
\text { antibody }\end{array}$ & Skin cancer & Tobacco & $\begin{array}{l}\text { CaMV35S/ } \\
\text { Agroinfiltration }\end{array}$ & $\begin{array}{l}1.2 \mathrm{mg} / \mathrm{kg} \\
\text { of leaves }\end{array}$ & Leaves & $\begin{array}{l}\text { Rodríguez } \\
\text { et al., } 2005\end{array}$ \\
\hline $\begin{array}{l}\text { Human } \\
\text { monoclonal } \\
\text { antibody 2F5 } \\
\end{array}$ & $\begin{array}{l}\text { Activity against } \\
\text { HIV-1 }\end{array}$ & Tobacco & $\begin{array}{l}\text { duplicated } \\
\text { CaMV35S }\end{array}$ & $\begin{array}{l}2.9 \mathrm{ug} / \mathrm{g} \\
\text { fresh weight }\end{array}$ & $\begin{array}{l}\text { Cell } \\
\text { suspension }\end{array}$ & $\begin{array}{l}\text { Sack et al., } \\
2007\end{array}$ \\
\hline $\begin{array}{l}\text { mAb BR55-2 } \\
\text { (IgG2a) }\end{array}$ & $\begin{array}{l}\text { Carcinomas, } \\
\text { particularly breast } \\
\text { and colorectal } \\
\text { cancers }\end{array}$ & Tobacco & CaMV $35 S$ & $\begin{array}{l}30 \mathrm{mg} \mathrm{kg} \text { of } \\
\text { fresh leaves }\end{array}$ & Leaves & $\begin{array}{l}\text { Brodzik et } \\
\text { al., } 2006\end{array}$ \\
\hline $\begin{array}{l}\text { LO-BM2, a } \\
\text { therapeutic } \\
\text { IgG antibody }\end{array}$ & $\begin{array}{l}\text { Possible tool to } \\
\text { prevent graft } \\
\text { rejection }\end{array}$ & Tobacco & En2pPMA4 & $\begin{array}{l}99 \text { ug in the } \\
\text { cell extract } \\
\text { of a } 100-\mathrm{ml} \\
\text { culture, } \\
12.81 \mathrm{ug} . \\
\text { medium- } \\
\text { associated } \\
\text { antibody }\end{array}$ & $\begin{array}{l}\text { Leaf and cell } \\
\text { suspension } \\
\text { culture }\end{array}$ & $\begin{array}{l}\text { De Muynck } \\
\text { et al., } 2009\end{array}$ \\
\hline $\begin{array}{l}\text { Monoclonal } \\
\text { antibody H10 } \\
(\mathrm{mAb} \mathrm{H} 10)\end{array}$ & $\begin{array}{l}\text { Tumour-associated } \\
\text { antigen tenascin-C } \\
\text { (TNC) }\end{array}$ & Tobacco & $\begin{array}{l}\text { CaMV 35S with } \\
\text { omega } \\
\text { translational } \\
\text { enhancer } \\
\text { sequence from } \\
\text { (TMV) }\end{array}$ & $\begin{array}{l}50-100 \\
\mathrm{mg} / \mathrm{kg} \text { fresh } \\
\text { plant tissue }\end{array}$ & Leaves & $\begin{array}{l}\text { Villani et } \\
\text { al., } 2009\end{array}$ \\
\hline
\end{tabular}

Table 2. Plant derived antibodies. 


\subsection{Plant derived vaccines}

Plants can be used to produce inexpensive and highly immunogenic vaccines. It is connected with heterologous expression of antigens. These are further purified to formulate injectable vaccine or are applied as edible vaccines. The latter idea is a very attractive alternative to injection, mostly because of low costs (no need for protein purification) and comfort of administration. However, there are some essential conditions which have to be satisfied. First of all, plants used for oral vaccine production should produce edible parts that can be consumed uncooked (antigens are often heat sensitive). Besides, these parts should be rich in protein because the antigen protein will constitute only a minor portion (0.01-0.4\%) of TSP. Seeds seems to be a good choice because of antigen extended stability, even at ambient storage temperatures. As many studies revealed, vaccine antigens present in plant tissues were resistant to digestion in the gastrointestinal tract, on the other hand during this process they were release to elicite both mucosal and systemic immune responses (Sharma and Sood, 2011). Current progress in the matter is summarized in Table 3.

\begin{tabular}{|c|c|c|c|c|c|c|}
\hline Vaccines & Disease & Plant & Promoter & $\begin{array}{l}\text { Expression } \\
\text { level }\end{array}$ & Organ & References \\
\hline $\begin{array}{l}\text { Subunit } \\
\text { HAC1 and } \\
\text { HAI-05 }\end{array}$ & $\begin{array}{l}\text { H1N1, H5N1 } \\
\text { influenza }\end{array}$ & Tobacco & Not reported & $\begin{array}{l}\text { HAC1 } 90 \\
\mathrm{mg} / \\
\text { and HAI-05 } \\
50 \mathrm{mg} / \mathrm{kg} \text { of } \\
\text { plant } \\
\text { biomass }\end{array}$ & Leaves & $\begin{array}{l}\text { Shoji et al., } \\
2011\end{array}$ \\
\hline $\begin{array}{l}\text { VP1-capsid } \\
\text { protein }\end{array}$ & $\begin{array}{l}\text { FMDV ( Foot } \\
\text { and Mouth } \\
\text { Disease } \\
\text { Virus) }\end{array}$ & Tobacco & $p s b A$ & $51 \%$ TSP & $\begin{array}{l}\text { Leaves } \\
\text { (Chloroplasts) }\end{array}$ & $\begin{array}{l}\text { Lentz et al., } \\
2010\end{array}$ \\
\hline TonB protein & $\begin{array}{l}\text { Immunizatio } \\
\mathrm{n} \text { against } \\
\text { Helicobacter } \\
\text { infections }\end{array}$ & A. thaliana & CaMV $35 S$ & $0.05 \%$ TSP & Entirely plant & $\begin{array}{l}\text { Kalbina et al., } \\
2010\end{array}$ \\
\hline $\begin{array}{l}\text { Mycobacteria } \\
1 \text { antigens } \\
\text { Ag85B }\end{array}$ & $\begin{array}{l}\text { Vaccine } \\
\text { against } \\
\text { tuberculosis }\end{array}$ & Tobacco & CaMV $35 S$ & $4 \%$ TSP & Leaves & $\begin{array}{l}\text { Floss et al., } \\
2010\end{array}$ \\
\hline $\begin{array}{l}\text { Surface } \\
\text { protein 4/5 } \\
\text { (PyMSP4/5) }\end{array}$ & Plasmodium & Tobacco & $\begin{array}{l}\text { MagnICON® } \\
\text { viral vector } \\
\text { system }\end{array}$ & $\begin{array}{l}10 \% \text { TSP or } \\
1-2 \mathrm{mg} / \mathrm{g} \text { of } \\
\text { fresh weight }\end{array}$ & Leaves & $\begin{array}{l}\text { Webster et al. } \\
2009\end{array}$ \\
\hline $\begin{array}{l}\text { TetC and } \\
\text { PTX S1 } \\
\text { antigens }\end{array}$ & $\begin{array}{l}\text { DTP } \\
\text { (diphtheria- } \\
\text { tetanus- } \\
\text { pertussis) }\end{array}$ & $\begin{array}{l}\text { Tobacco } \\
\text { Daucus } \\
\text { carrota }\end{array}$ & CaMV $35 S$ & Not reported & $\begin{array}{l}\text { Leaves; } \\
\text { Hypocotyls }\end{array}$ & $\begin{array}{l}\text { Brodzik et al., } \\
2009\end{array}$ \\
\hline $\begin{array}{l}\mathrm{HN} \\
\text { glycoprotein }\end{array}$ & $\begin{array}{l}\text { Newcastle } \\
\text { Disease Virus } \\
\text { (NDV) }\end{array}$ & Tobacco & P-RbcS & $\begin{array}{l}3 \mu g \text { of } \\
\text { HN protein } \\
\text { per mg of } \\
\text { total leaf } \\
\text { protein }\end{array}$ & Leaves & $\begin{array}{l}\text { Gómeza et } \\
\text { al., } 2009\end{array}$ \\
\hline HBsAg & $\begin{array}{l}\text { HBV } \\
\text { (hepatitis B } \\
\text { virus) }\end{array}$ & Lactuca sativa & CaMV $35 S$ & Not reported & Shoots & $\begin{array}{l}\text { Marcondes \& } \\
\text { Hansen, } 2008\end{array}$ \\
\hline
\end{tabular}




\begin{tabular}{|c|c|c|c|c|c|c|}
\hline Vaccines & Disease & Plant & Promoter & $\begin{array}{l}\text { Expression } \\
\text { level }\end{array}$ & Organ & References \\
\hline $\begin{array}{l}\text { HPV-16 L1 } \\
\text { protein }\end{array}$ & $\begin{array}{l}\text { HPV (Human } \\
\text { Papilloma } \\
\text { Virus) }\end{array}$ & Tobacco & $\begin{array}{l}\text { psbA } \\
\text { promoter }\end{array}$ & $24 \%$ TSP & Leaves & $\begin{array}{l}\text { Fernández- } \\
\text { San Millán et } \\
\text { al. } 2008\end{array}$ \\
\hline $\begin{array}{l}16 \text { E7 } \\
\text { oncoprotein }\end{array}$ & HPV & $\begin{array}{l}\text { Tomato; } \\
\text { Potato }\end{array}$ & CaMV 35S & $\begin{array}{l}0.5 \% \text { of the } \\
\text { cell } \\
\text { protein- } \\
\text { potato }\end{array}$ & $\begin{array}{l}\text { Potato } \\
\text { protoplast; } \\
\text { leaves }\end{array}$ & $\begin{array}{l}\text { Briza et al., } \\
2007\end{array}$ \\
\hline G protein & Rabies virus & Daucus carotta & CaMV 35S & $\begin{array}{l}0.2-1.4 \% \\
(\mathrm{TSP})\end{array}$ & Carrot roots & $\begin{array}{l}\text { Royas-Anaya } \\
\text { et al., } 2009\end{array}$ \\
\hline $\begin{array}{l}\text { Capsid } \\
\text { protein VP6 }\end{array}$ & Rotavirus & Potato & $\mathrm{P} 2$ & $0.01 \%$ & $\begin{array}{l}\text { Leaves, } \\
\text { tubers }\end{array}$ & $\begin{array}{l}\text { Yu \& } \\
\text { Landgridge, } \\
2003\end{array}$ \\
\hline
\end{tabular}

Table 3. Plant derived vaccines.

\subsection{Plant derived biopharmaceuticals}

Plants can be used to produce inexpensive biopharmaceuticals (Table 4).

\begin{tabular}{|c|c|c|c|c|c|}
\hline Biopharmaceutical & $\begin{array}{l}\text { Potential } \\
\text { application }\end{array}$ & Plant & Promoter & Expression level & References \\
\hline IL-10 & $\begin{array}{l}\text { Inflammatory } \\
\text { and autoimmune } \\
\text { diseases }\end{array}$ & Rice seeds & $\begin{array}{l}\text { Glutelin B-1 } \\
\text { promoter }\end{array}$ & $2 \mathrm{mg}$ pure IL-10 & $\begin{array}{l}\text { Fujiwara et al., } \\
2010\end{array}$ \\
\hline Human transfferin & $\begin{array}{l}\text { Receptor- } \\
\text { mediated } \\
\text { endocytosis } \\
\text { pathway }\end{array}$ & Rice seeds & $\begin{array}{l}\text { Glutelin 1 G-1 } \\
\text { promoter }\end{array}$ & $1 \%$ seed dry weight & $\begin{array}{l}\text { Zhang et al., } \\
2010\end{array}$ \\
\hline $\begin{array}{l}\text { Glutamic acid } \\
\text { decarboxylase } \\
\text { (GAD65) }\end{array}$ & $\begin{array}{l}\text { Autoimmune } \\
\text { T1DM }\end{array}$ & $\begin{array}{l}\text { Tobacco } \\
\text { leaves }\end{array}$ & CaMV 35S & $\begin{array}{l}2.2 \% \text { total soluble } \\
\text { protein }\end{array}$ & $\begin{array}{l}\text { Avesani et al., } \\
2010\end{array}$ \\
\hline hGH, somatotropin & $\begin{array}{l}\text { Growth } \\
\text { hormone- } \\
\text { treatment of } \\
\text { dwarfism }\end{array}$ & $\begin{array}{l}N . \\
\text { benthamiana }\end{array}$ & CaMV 35S & $\begin{array}{l}60 \text { mg per kilogram } \\
\text { offresh tissue; } 7 \%\end{array}$ & $\begin{array}{l}\text { Rabindran et. } \\
\text { al., 2009; }\end{array}$ \\
\hline $\begin{array}{l}\text { Human } \\
\text { erythropoietin (EPO) }\end{array}$ & $\begin{array}{l}\text { Anemia, Renal } \\
\text { failure }\end{array}$ & N. tabacum & CaMV 35S & $\begin{array}{l}0.05 \% \text { of total } \\
\text { soluble protein }\end{array}$ & $\begin{array}{l}\text { Conley et al., } \\
2009\end{array}$ \\
\hline $\begin{array}{l}\text { Human serum } \\
\text { albumin (HSA) }\end{array}$ & Deficiences & $\begin{array}{l}\text { Tobacco, } \\
\text { potato }\end{array}$ & Prrn; B33 & $\begin{array}{l}11.1 \% \mathrm{TSP} \% \text { (tobacco } \\
\text { chloroplasts); } \\
0.2 \% \text { TSP (potato } \\
\text { tuber) }\end{array}$ & $\begin{array}{l}\text { Faran et al., } \\
2002\end{array}$ \\
\hline $\begin{array}{l}\text { Human lactoferrin } \\
(\mathrm{hLF})\end{array}$ & $\begin{array}{l}\text { Anti- } \\
\text { inflammatory } \\
\text { and immuno- } \\
\text { modulation } \\
\text { effects }\end{array}$ & Potato & $\begin{array}{l}\text { Tandem } \\
\text { promoter: } \\
\text { P2\& CaMV } \\
\text { 35S }\end{array}$ & $0.10 \% \mathrm{TSP}$ & $\begin{array}{l}\text { Chong et al., } \\
2000\end{array}$ \\
\hline Enkephalins & Painkiller & $\begin{array}{l}\text { Cress, } A \text {. } \\
\text { thaliana }\end{array}$ & 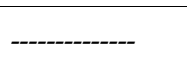 & $0.10 \%$ seed protein & $\begin{array}{l}\text { Daniell et al., } \\
2001\end{array}$ \\
\hline Staphylokinase & $\begin{array}{l}\text { Thrombolytic } \\
\text { factor }\end{array}$ & A. thaliana & CaMV 35S & not reported & $\begin{array}{l}\text { Wiktorek- } \\
\text { Smagur et al., } \\
2011\end{array}$ \\
\hline
\end{tabular}

Table 4. Plant derived biopharmaceuticals. 


\subsection{Nutraceutical and non-pharmaceutical plant derived proteins}

Antimicrobial nutraceutics, such as human lactoferrin and lysozymes, have now been successfully produced in several crops (Stefanova et al., 2008), and are commercially available (Table 5). Cobento Biotechnology (Denmark) has recently received approval for its Arabidopsis derived human intrinsic factor which is used against vitamin B12 deficiency and it is now commercially available as Coban. Other nutraceutical products are listed in Table 5.

Trypsin is a proteolytic enzyme that is used in a variety of commercial applications, including processing of some biopharmaceuticals (Sharma \& Sharma, 2009). In 2004, the first plant derived recombinant protein product (bovine sequence trypsin; trade name trypZean) developed in corn plant (Prodi Gene, USA) was commercialized. Avidin, a glycoprotein found in avian, reptilian and amphibian egg white, is primarily used as a diagnostic reagent. The plant optimized avidin coding sequence was expressed in corn and now it is available on the market. $\beta$-glucuronidase, peroxidase, laccase, cellulase, aprotinin were also developed and marketed (Basaran \& Rodrigez-Cerezo, 2008).

Spider silk proteins, elastin and collagen, have been expressed in transgenic plants (Scheller et al., 2004). These are promising biomaterials for regenerative medicine.

\begin{tabular}{|c|c|c|c|c|}
\hline Product name & Company name & Plant & $\begin{array}{l}\text { Commercial } \\
\text { name }\end{array}$ & Source \\
\hline Avidin & Prodigene & Corn & Avidin & Obembe at al., 2011 \\
\hline$\beta$-glucuoronidase & Prodigene & Corn & GUS & Obembe at al., 2011 \\
\hline Trypsin & Prodigene & Corn & TrypZean & Obembe at al., 2011 \\
\hline $\begin{array}{l}\text { Recombinant human } \\
\text { lactoferrin }\end{array}$ & $\begin{array}{l}\text { Meristem } \\
\text { Therapeutic, } \\
\text { Ventria } \\
\text { Bioscience }\end{array}$ & Corn, Rice & Lacromin & $\begin{array}{l}\text { http://www.meristemthera- } \\
\text { peutics.com }\end{array}$ \\
\hline $\begin{array}{l}\text { Recombinant human } \\
\text { lysozyme }\end{array}$ & $\begin{array}{l}\text { Ventria } \\
\text { Bioscience }\end{array}$ & Rice & Lysobac & http://www.ventria.com \\
\hline Aprotinin & Prodigene & $\begin{array}{l}\text { Corn, } \\
\text { Tobacco }\end{array}$ & AproliZean & Obembe at al., 2011 \\
\hline Recombinant lipase & $\begin{array}{l}\text { Meristem } \\
\text { Therapeutic }\end{array}$ & Corn & Merispase & $\begin{array}{l}\text { http://www.meristemthera } \\
\text { peutics.com }\end{array}$ \\
\hline $\begin{array}{l}\text { Recombinant human intrinsic } \\
\text { factor }\end{array}$ & $\begin{array}{l}\text { Cobento Biotech } \\
\text { AS }\end{array}$ & Arabidopsis & Coban & http://www.cobento.dk \\
\hline Human growth factors & ORF Genetics & Barley & ISOkine $^{\mathrm{TM}}$ & http://www.orfgenetics.com \\
\hline Food additive for shrimps & SemBioSys & Safflower & $\begin{array}{l}\text { Immuno- } \\
\text { spherte }\end{array}$ & http://www.sembiosys.com \\
\hline
\end{tabular}

Table 5. Transgenic plants based on products commercially available in the market. 


\section{Recombinant protein purification}

\subsection{Affinity chromatography}

Isolation and purification of a biologically active protein from a crude lysate is often difficult and costly. Simple, cheap and more efficient strategies of its purification on the laboratory and industrial scale are thus on great demand. One of the numerous approaches in this field is an affinity tags system easily applicable for recombinant protein purification by affinity chromatography. The term 'affinity chromatography' was introduced in 1968 by Pedro Cuatrecasas, Meir Wilchek, and Christian B. Anfinsen (1968). Now it is the method of choice (Kabir et al., 2010). Affinity chromatography is based on specific interaction between two molecules in order to isolate the protein of interest from a pool of unwanted proteins and other contaminants. For this purpose a fusion protein is created. A short fragment of DNA can be ligated to the 5 ' or $3^{\prime}$ - terminus of the target gene. This peptide or protein coding sequence (so called tag), which is translated in frame with protein of interest exhibits a characteristic property, strong and selective binding to the molecules immobilized on the solid matrices (Fong et al., 2010). Purification process is effective and simple. During passage of the cell extract containing the fusion protein and contaminants through an appropriate column the tagged protein is retained, while all the others migrate freely through the column (Fig. 1).

In the next step, the bound protein is eluted by a change in buffer composition / parameters (i.e. competitors, chelators, $\mathrm{pH}$, ionic strength or temperature). Affinity tags are divided into three main classes according to their properties and the properties of molecules that interact with them: 1) tags, binding to small molecule ligands linked to a solid support (i.e. HIS-tag), 2) protein tags binding to a macromolecular partner immobilized on chromatography support (i.e. CBP-tag), 3) the protein-binding partner attached to the resin in an antibody which recognizes a specific peptide epitope in a recombinant protein (i.e. FLAG-tag) (Lichty et al., 2005, Arnau et al., 2006, Waugh et al., 2005). To date large number of gene fusion tags has been described, the most commonly used ones are presented in Table 6.

\begin{tabular}{lll}
\hline Tag & Comments & References \\
\hline His-tag & $\begin{array}{l}\text { Purification by interaction between } \\
\text { immobilized metal ions and chelating amino } \\
\text { acids }\end{array}$ & $\begin{array}{c}\text { Valdez-Ortiz et al., 2005, } \\
\text { Vaquero et al., 2002 }\end{array}$ \\
\hline FLAG & $\begin{array}{l}\text { Purification based on binding the FLAG } \\
\text { peptide to antibodies }\end{array}$ & $\begin{array}{l}\text { Brodzik et al., 2009, } \\
\text { Zhou and Li., 2005 }\end{array}$ \\
\hline Strep-tag II & $\begin{array}{l}\text { Strong specific interaction between Streptag } \\
\text { and strep-Tactin (streptavidin derivate) } \\
\text { immobilised on resin }\end{array}$ & Witte et al., 2004 \\
\hline
\end{tabular}

Table 6. Some examples of affinity tags commonly used for protein purification. 


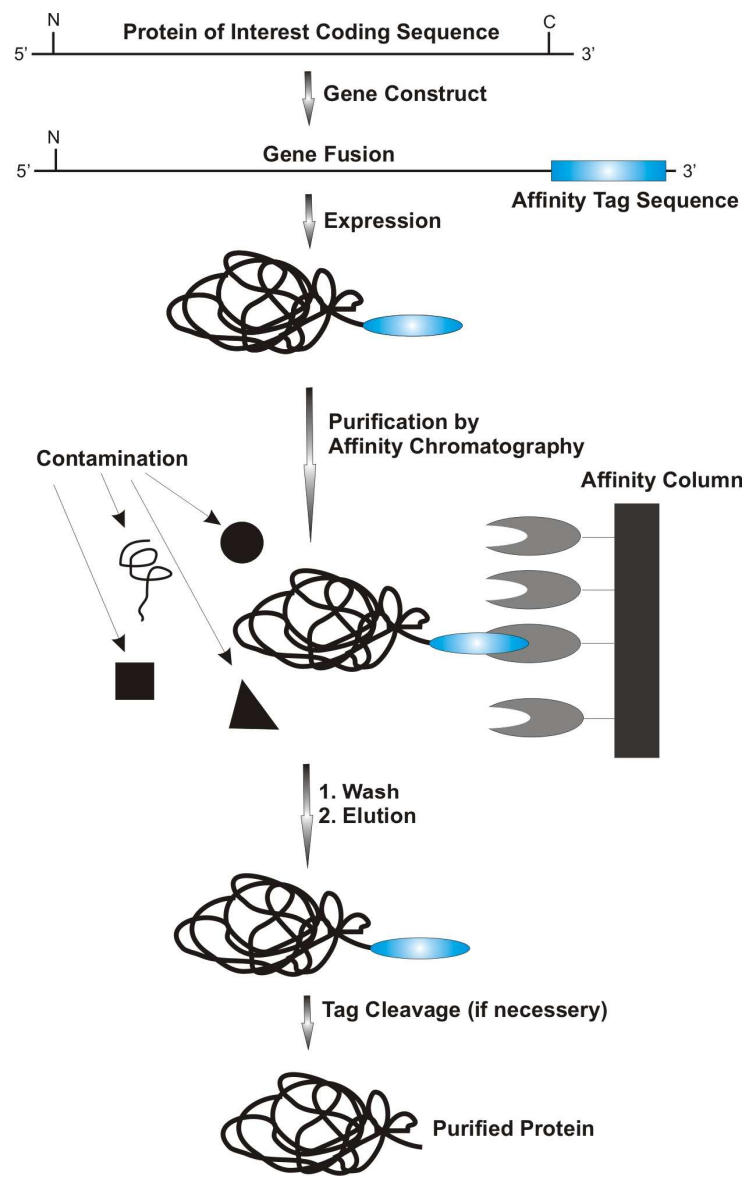

Fig. 1. Schematic representation of the recombinant protein purification process by affinity chromatography (Hearn \& Acosta, 2001, modified).

\subsection{Elastin-like polypeptides in recombinant protein purification}

While affinity chromatography is used for purification of a broad spectrum of recombinant proteins it is not free from drawbacks. The main limitations associated with the use of this method are: 1) high cost of chromatography packing materials, 2) volume-limited sample throughput, 3) dilution of the protein product in elution buffer, 4) additional concentration step may cause loss in protein yield (Chow et al., 2008). Taking into account the above, there is a need to introduce new alternative methods for purification of recombinant proteins.

One of the possible solutions is application of non-chromatographic purification tags. Elimination of resins allows us to reduce some of the aforementioned problems.

Elastin-like polypeptides (ELP), artificial polymers containing Val-Pro-Gly-Xaa-Gly pentapeptide repeats, are an example of such tags. Such repeats occur naturally in the 
hydrophobic domain of human tropoelastin (soluble precursor of elastin) and they play an important role in the process of elastin formation (Mithieux \& Weiss 2005, Valiaev et al., 2008). Xaa (so called guest residue) in the ELP sequence can contain any amino acid except for proline (Meyer \& Chilkoti, 1999). Occurrence of proline at these positions eliminates distinctive and very useful properties of these polymers (Trabbic-Carlson et al., 2004). Literature classification of ELP is based on the type and number of amino acids present in the guest residue positions (Meyer \& Chilkoti 2004).

Elastin-like polypeptides belong to one of the three classes of thermosensitive biopolymers (Mackay and Chilkoti, 2008) whose properties are changed under the influence of moderate temperature differences. Aqueous solutions of ELP exhibit lower critical solution temperature (LCST) which causes that the above phase transition temperature $\left(\mathrm{T}_{\mathrm{t}}\right)$ ELP pass from soluble to an insoluble form (Ge et al., 2006) in a narrow temperature range $\left(\sim 2{ }^{\circ} \mathrm{C}\right.$ ) (Ge and Filipe, 2006). This is a reversible process called coacervation. In solutions with temperature below $T_{t}$, free polymer chains remain in a disordered soluble form. The opposite occurs in solutions with temperatures above $T_{t}$, when the polymer chains have more ordered structure (called $\beta$-helix), stabilized by hydrophobic interactions (RodriguezCabello et al., 2007) that increase association of polymer chains (Serrano et al., 2007). This process is reversible. The fact that ELP - protein fusions are prone to reversible transition is of great importance (Kim et al., 2004). The process of ELP-tagged protein purification involves increasing ionic strength and/or temperature of the cell lysate to induce ELPfusion protein aggregation (Fig. 2). Next sample centrifugation/filtration separates the ELP fusion protein from contaminants. After resolubilization of an ELP fusion, another centrifugation/filtration removes denatured and aggregated biomolecules. This process called Inverse Transition Cycling (ITC) can be repeated to achieve the required purity of the product (Floss, Schallau et al., 2010).

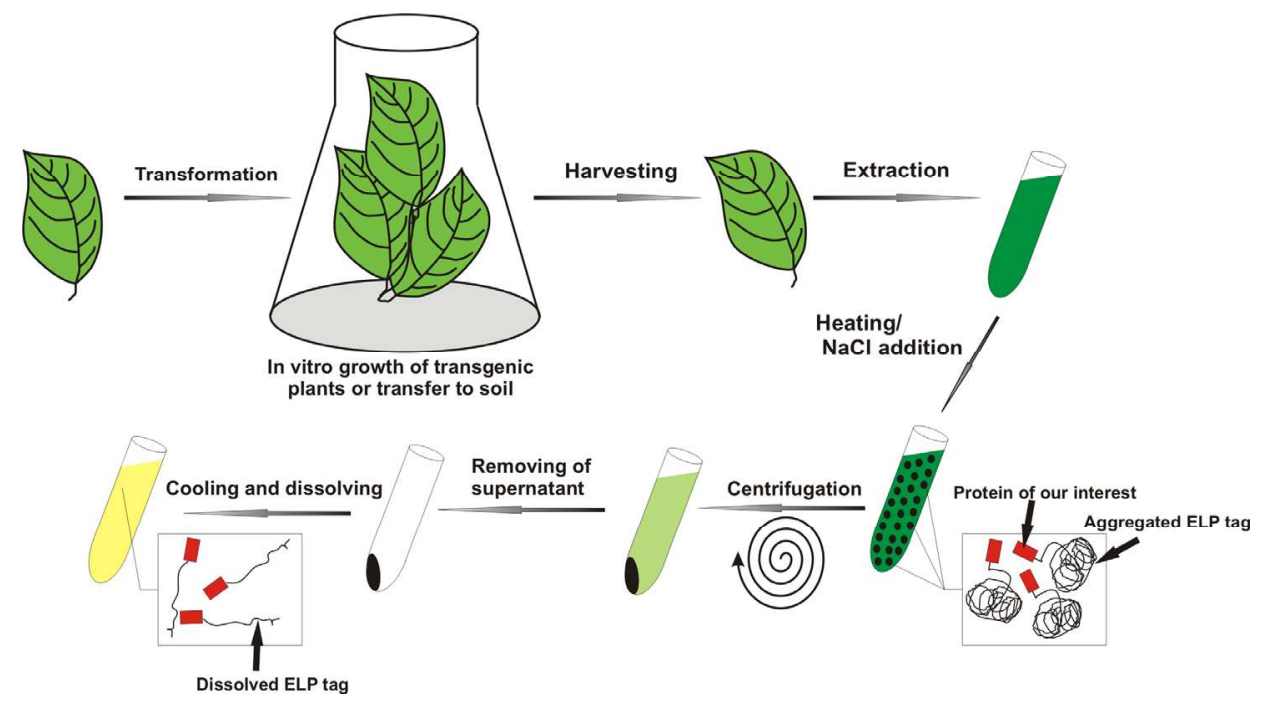

Fig. 2. Purification of ELPylated target proteins from plants using ITC (Floss et al., 2010 modified. 
Purification of proteins using elastin-like polypeptides has several advantages over the traditional chromatographic methods: 1) purification of proteins with ELP tags by ITC appears to be universal for soluble recombinant proteins, 2) chromatography beads are not required, which significantly reduces the costs, 3) final concentration step is not required (Chow et al., 2008).

\subsection{Application of ELP to the process of production and purification of recombinant proteins in transgenic plants}

Scheller and co-workers (2004) achieved efficient and stable expression of spider's silk-ELP fusion protein in the ER of transgenic tobacco and potato. Application of ITC allowed them to obtain $80 \mathrm{mg}$ pure recombinant protein from $1 \mathrm{~kg}$ tobacco leaf material. Purified biopolymer was tested as a potential component used for the cultivation of anchoragedependent $\mathrm{CHO}-\mathrm{K} 1$ cells and human chondrocytes. The most common coating substances such as collagen, fibronectin and laminin are derived from animal sources, so there is a risk of contamination of cell cultures by viruses or prions which is essentially undesirable in the case of medical applications. What is more, production of this fusion protein in plants is less costly. Lin and associates (2006) obtained active soluble glycoprotein 130 which seems to be potent drug in Crohn's disease, rheumatoid arthritis and colon cancer therapy. This work a presents creation and expression of mini-gp130-ELP. A fusion protein containing Ig-like domain and cytokine binding module of gp 130 fused to 100 repeats of ELP was expressed in tobacco leaves (ER retention). Inverse transition cycling (ITC) purification resulted in 141 $\mu \mathrm{g}$ of active mini-gp130-ELP per $1 \mathrm{~g}$ of leaf fresh weight. Floss and co-workers (2010) demonstrated the ability of genetically engineered tobacco to produce mycobacterial antigens Ag85B and ESAT-6 as the vaccine against tuberculosis. In this work Ag85B-ELP and ESAT-6-ELP (TBAg) fusions were created, purified by inverse transition cycling and tested on animals. Production of this TBAg-ELP fusion proteins reached $4 \%$ of the tobacco leaf total soluble proteins (TSP) for the best producer plants. Further testing of the vaccine showed mycobacterium-specific immune response with no side effects in an animal model. What is more, this study also confirmed that ELP had no immunomodulating activity. Joensuu and co-workers (2009) demonstrated ELP application in production of antibodies for Foot-and-mouth disease virus (FMDV) therapy. Single chain variable antibody fragment $(\mathrm{scFv})$ recognizing FMDV coat protein VP1 was expressed in transgenic tobacco plants. To recover the fusion protein in the active form the plants, ITC was performed. Finally, the authors demonstrated that $\mathrm{scFv}$ expressed in plants were able to bind FMDV.

It has been shown for spider silk proteins (Scheller et al., 2004), murine interleukin-4, human interleukin-10 (Patel et al., 2007) and anti-HIV type 1 antibodies (Floss et al., 2008, Floss et al., 2009) that the ELP fusion significantly enhances accumulation of recombinant proteins produced in plants. So far the mechanism of that phenomenon is not known.

\section{Status of plant-derived biopharmaceuticals in clinical development}

At present some non-pharmaceutical products from plants are on the market (Basaran and Rodriguez-Cerezo, 2008). Although no plant made pharmaceutical (PMP) has been commercialized as a human drug, several PMPs are at the late stage of development and some have already received regulatory approval, including a vaccine and several nutraceuticals (Table,7, 8, 9). 


\begin{tabular}{llllll}
\hline Antibodies & Target & Plant & $\begin{array}{l}\text { Clinical } \\
\text { trial status }\end{array}$ & Company & Source \\
\hline DoxoRx & $\begin{array}{l}\text { Side-effects } \\
\text { of cancer } \\
\text { therapy }\end{array}$ & Tobacco & Phase I & $\begin{array}{l}\text { Planet } \\
\text { Biotechnology }\end{array}$ & $\begin{array}{l}\text { http://www.planet } \\
\text { biotechnology.com }\end{array}$ \\
\hline RhinoRX & $\begin{array}{l}\text { Common } \\
\text { cold }\end{array}$ & Tobacco & Phase I & $\begin{array}{l}\text { Planet } \\
\text { Biotechnology }\end{array}$ & $\begin{array}{l}\text { http://www.planet } \\
\text { biotechnology.com }\end{array}$ \\
\hline IgG (ICAM1) & $\begin{array}{l}\text { Common } \\
\text { cold }\end{array}$ & Tobacco & Phase I & $\begin{array}{l}\text { Planet } \\
\text { Biotechnology }\end{array}$ & $\begin{array}{l}\text { http://www.planet } \\
\text { biotechnology.com }\end{array}$ \\
\hline CaroRX & $\begin{array}{l}\text { Dental } \\
\text { caries }\end{array}$ & Tobacco & $\begin{array}{l}\text { EU } \\
\text { approved } \\
\text { as medical } \\
\text { advice }\end{array}$ & $\begin{array}{l}\text { Planet } \\
\text { Biotechnology, }\end{array}$ & $\begin{array}{l}\text { hiotechnology.com } \\
\text { bitt/ }\end{array}$ \\
\hline
\end{tabular}

Table 7. Plant derived antibodies in clinical phages of development.

\begin{tabular}{|c|c|c|c|c|c|}
\hline Antigen or vaccine & Disease & Plant & $\begin{array}{l}\text { Clinical } \\
\text { trial status }\end{array}$ & Company & Source \\
\hline Hepatitis B antigen & Hepatitis B & Lettuce & Phase I & $\begin{array}{l}\text { Thomas } \\
\text { Jefferson } \\
\text { University }\end{array}$ & Streatfield, 2006 \\
\hline Hepatitis B antigen & Hepatitis B & Potato & Phase II & $\begin{array}{l}\text { Arizona } \\
\text { State } \\
\text { University }\end{array}$ & Streatfield, 2006 \\
\hline Fusion proteins & Rabies & Spinach & Phase I & $\begin{array}{l}\text { Thomas } \\
\text { Jefferson } \\
\text { University }\end{array}$ & http://www.labome.org \\
\hline $\begin{array}{l}\text { Heat labile toxin B } \\
\text { subunit of E.coli }\end{array}$ & Diarrhea & Potato & Phase I & ProdiGene & Tacket, 2005 \\
\hline $\begin{array}{l}\text { Capsid protein } \\
\text { Norwalk virus }\end{array}$ & Diarrhea & Potato & Phase I & $\begin{array}{l}\text { Arizona } \\
\text { State } \\
\text { University }\end{array}$ & Khalsa et al., 2004 \\
\hline Vibrio cholerae & Cholera & Potato & Phase I & $\begin{array}{l}\text { Arizona } \\
\text { State } \\
\text { University }\end{array}$ & Tacket, 2005 \\
\hline $\begin{array}{l}\text { HN protein of } \\
\text { Newcastle disease } \\
\text { virus }\end{array}$ & $\begin{array}{l}\text { Newcastle } \\
\text { disease } \\
\text { (Poultry) }\end{array}$ & Tobacco & $\begin{array}{l}\text { USDA } \\
\text { Approved }\end{array}$ & $\begin{array}{l}\text { Dow Agro } \\
\text { Sciences }\end{array}$ & http://www.dowagro.com \\
\hline $\begin{array}{l}\text { Viral vaccine } \\
\text { mixture }\end{array}$ & $\begin{array}{l}\text { Diseases of } \\
\text { horses, dogs }\end{array}$ & Tobacco & Phase I & $\begin{array}{l}\text { Dow Agro } \\
\text { Sciences }\end{array}$ & http://www.dowagro.com \\
\hline Poultry vaccine & $\begin{array}{l}\text { Coccidiosis } \\
\text { infection }\end{array}$ & Canola & Phase II & $\begin{array}{l}\text { Guardian } \\
\text { Bioscence }\end{array}$ & $\begin{array}{l}\text { Basaran \& Rodrigez-Cerezo, } \\
2008\end{array}$ \\
\hline $\begin{array}{l}\text { Gastroenteritis virus } \\
\text { (TGFV) capsid } \\
\text { protein }\end{array}$ & $\begin{array}{l}\text { Piglet } \\
\text { gastroenteritis }\end{array}$ & Maize & Phase I & ProdiGene & $\begin{array}{l}\text { Basaran \& Rodrigez-Cerezo, } \\
2008\end{array}$ \\
\hline $\begin{array}{l}\text { H5N1 vaccine } \\
\text { candidate }\end{array}$ & $\begin{array}{l}\text { H5N1 } \\
\text { pandemic } \\
\text { influenza }\end{array}$ & Tobacco & Phase I & Medicago & http://www.medicago.com \\
\hline
\end{tabular}

Table 8. Plant derived vaccines in clinical phages of development. 


\begin{tabular}{llllll}
\hline $\begin{array}{l}\text { Therapeutic } \\
\text { humans protein }\end{array}$ & Disease & Plant & $\begin{array}{l}\text { Clinical } \\
\text { trial } \\
\text { status }\end{array}$ & Company & Source \\
\hline a-Galactosidase & Fabry disease Tobacco & Phase I & $\begin{array}{l}\text { Planet } \\
\text { Biotechnology }\end{array}$ & $\begin{array}{l}\text { http://www.planet } \\
\text { biotechnology.com }\end{array}$ \\
\hline Lactoferon & Hepatitis C & Duckweed & Phase II & Biolex & http://www.biolex.com \\
\hline Fibrinolytic drug & Blood clot & Duckweed Phase I & Biolex & http://www.biolex.com \\
\hline $\begin{array}{l}\text { Human } \\
\text { glucocerebrosidase }\end{array}$ & $\begin{array}{l}\text { Gaucher's } \\
\text { disease }\end{array}$ & Carrot & $\begin{array}{l}\text { Waiting } \\
\text { USDA's } \\
\text { approval }\end{array}$ & $\begin{array}{l}\text { Prostalix } \\
\text { Biotherapeutic }\end{array}$ & http.//www.prostalix.com \\
\hline Insulin & Diabetes & Safflower & Phase III & SemBioSys & http.//www.sembiosysys.com \\
\hline Apolipoprotein & $\begin{array}{l}\text { Cardio } \\
\text { vascular }\end{array}$ & Safflower & Phase I & SemBioSys & http.//www.sembiosysys.com \\
\hline
\end{tabular}

Table 9. Plant derived pharmaceuticals in clinical phages of development.

In 2006 the world's first plant made vaccine candidate for Newcastle disease in chickens, produced in a suspension cultured tobacco cell line by Dow Agro Science, was registered and approved by the US Department of Agriculture (USDA) - the final authority for veterinary vaccines. In addition, two plant made pharmaceuticals are moving through Phase II and Phase III human clinical trials. Biolex's product candidate, Locteron ${ }^{\circledR}$, is in Phase IIb clinical testing for the treatment of chronic hepatitis CA. This company uses two genera, Lemna and Spirodela, as a platform for production of their biopharmaceuticals. The positive outcome of Phase III trials of Protalix's glucocerebrosidase (UPLYSO®) for the treatment of Gaucher's disease which is now waiting for USDA's approval is another positive example. The successful completion of Phase III trial that concerned SemBioSys insulin bioequivalent of the commercial standard represents an important landmark in the plant made pharmaceuticals scenario and, most likely, in the next few years recombinant human insulin produced in safflower will become commercially available for diabetic people.

Medicago Inc. of Canada was invited to the sixth WHO meeting about evaluation of pandemic influenza prototype vaccines in clinical trials. One of the purposes of this meeting was to make recommendations on research activities that will contribute to the development of effective pandemic vaccines. Medicago has recently reported positive results from a Phase I human clinical trial with its H5N1 avian influenza vaccine candidate (a VLP based vaccine produced with a transient expression system). The vaccine was found to be safe, well tolerated and it also induced a solid immune response. Based on these results, Medicago will process with Phase II clinical trial with the first plant made influenza vaccine (Franconi et al., 2010). These examples will pave the way to easy public acceptance of transgenic plants as new production platforms for human therapeuticals.

\section{Concluding remarks}

Biopharming is still a relatively new field in plant science but in the coming years it may become the premier expression system for a wide variety of new biopharmaceuticals. The use of plants as factories for the synthesis of therapeutic protein molecules will undoubtedly develop. Since the first development of a genetically modified plant in 1984, numerous comprehensive review articles have been published demonstrating the tremendous potential of plants for pharmaceutical production. As it has been clearly shown plants are no 
longer considered only in terms of diet or beauty. The proteins targeted for biopharmaceutical technology form three broad categories: antibodies, vaccines, and other therapeutics. Plant bioreactors represent an attractive alternative for their synthesis requiring the lowest capital investment of all tested production systems. The events of heterologous proteins in planta production were rapidly followed with development/improvement of significant technologies (e.g. DNA delivery systems, selection methods). At present a number of promoters with tissue-specific activity or subcellular targeting sites that offer protein stability are known and many are still under intense study. Obviously, the construction of a transgenic plant synthesizing a functional therapeutic is a multidisciplinary process and the society of biotechnologists takes a keen interest in its success. However, over the past years various plant expression platforms have been tested and it is evident that further development and improvement are needed for more effective molecular farming. Apart from continuously increasing transgene yields efforts will need to ensure that plant-derived biopharmaceuticals would meet the same safety and efficacy standards as products of non-plant origin. There is no doubt that sooner or later the scientific limitations of molecular farming will be overcome, especially when numerous therapeutics and plant platforms are developed by many laboratories and companies. Thus, this is the regulatory requirements and public acceptance which are the greatest challenge of modern plant biotechnology. Of course, molecular farming raises less objection than technologies using genetically modified animals, but still the existing or proposed regulations remain based on public fears rather than on scientific facts.

In conclusion, "the molecular farming industry" means a natural advance in drug production technology. The dynamics of optimization and improvement of plant expression platforms illustrates its potential and tremendous scientific background. The possible success in this field will have to face the question of public acceptance. Thus, the scientists should send the clear massage to the public opinion that molecular farming is a strictly controlled technology that has strong benefits. And that probably will be more difficult than the construction of functional bioreactor itself.

\section{References}

Almquist, KC.; McLean, MD.; Niu, Y.; Byrne, G.; Olea-Popelka, FC.; Murrant, C.; Barclay, J. \& Hall, JC. (2006). Expression of an anti-botulinum toxin A neutralizing singlechain Fv recombinant antibody in transgenic tobacco. Vaccine, Vol. 24, No. 12, (December, 2006), pp. 2079-2086, ISSN 0264-410X

Arnau, J.; Lauritzen, C.; Petersen, GE. \& Pedersen, J. (2006). Current strategies for the use of affinity tags and tag removal for the purification of recombinant proteins. Protein Expression and Purification, Vol. 48, No. 1,(July 2006) pp. 1-13, ISSN 1046-5928

Avesani, A.; Vitale, A.; Pedrazzini, E.; de Virgilio, M.; Pompa, A.; Barbante, A.; Gecchele, E.; Dominici, P.; Morandini, F.; Brozzetti, A.; Falorni, A. \& Mario Pezzotti, M. (2010). Recombinant human GAD65 accumulates to high levels in transgenic tobacco plants when expressed as an enzymatically inactive mutant. Plant Biotechnology Journal, Vol. 8, No. 8, (September 2010), pp. 862-872, ISSN 14677644

Basaran, P. \& Rodriguez-Cerezo, E. (2008). Plant molecular farming: opportunities and challenges. Critical Reviws in Biotechnology, Vol. 28, No. 3, (March 2008), pp. 153-172, ISSN 1549-7801. 
Boehm, R. (2007). Bioproduction of Therapeutic Proteins in the 21st Century and the Role of Plants and Plant Cells as Production Platforms. Annals of the New York Academy of Sciences, Vol. 1102, (April 2007), pp. 121-134, ISSN 1749-6632

Briza, J.; Pavingerowa, D.; Vlasak, J.; Ludvikova, V. \& Niedermeierova, H. (2007). Production of human papillomavirus type 16 E7 oncoprotein fused with $\beta$-glucuronidase in transgenic tomato and potato plants. Biologia Plantaru ,Vol 51, No. 2, (June 2007), pp. 268-276, ISSN 0006-3134

Brodzik, R.; Glogowska, M.; Bandurska, K.; Okulicz, M.; Deka, D.; Ko, K.; van der Linden, J.; Leusen, JH.; Pogrebnyak, N.; Golovkin, M.; Steplewski, Z. \& Koprowski, H. (2006). Plant-derived anti-Lewis $Y$ mAb exhibits biological activities for efficient immunotherapy against human cancer cells. Proceedings of the National Academy of Sciences of the United States of America, Vol. 103, No. 23, (May 2006), pp. 8804-8809, ISSN 0027-8424

Brodzik, R.; Spitsin, S.; Pogrebnyak, N.; Bandurska, K.; Portocarrero, C.; Andryszak, K.; Koprowski, H. \& Golovkin M. (2009). Generation of plant-derived recombinant DTP subunit vaccine. Vaccine, Vol. 27, No. 28, (June 2009), pp. 3730-3734, ISSN 0264-410X

Cardi, T.; Lenzi, P. \& Maliga, P. (2010). Chloroplast as expression platforms for plant produced vaccines. Expert Review of Vaccines, Vol. 9, No. 8, (October 2009), pp. 893911, ISSN 1476-0584.

Chan, MT. \& Yu, SM. (1998). The 3' untranslated region of a rice alpha amylase gene function as a sugar dependent mRNA stability determinant. Proceedings of the National Academy of Sciences of the United States of America, Vol. 95, No. 11, (May 1988), pp. 6543-6547, ISSN 0027-8424.

Chen, ZL.; Schuler, MA. \& Beachy, RN. (1986). Functional analysis of regulatory elements in a plant embryo specific gene. Proceedings of the National Academy of Sciences of the United States of America, Vol. 83, No. 22, (November 1986), pp. 8560-9564, ISSN 0027-8424.

Chong, D.K.X. \& Langridge, W.H.R. (2000). Production of full- length bioactive antimicrobial human lactoferrin in potato plants. Transgenic Research, Vol. 9, No. 1, (January 2000), pp. 71-78, ISSN 0962-8819

Chow, D.; Nunalee, ML.; Lim, DW.; Simnick, AJ. \& Chilkoti., A. (2008). Peptide-based Biopolymers in Biomedicine and Biotechnology. Materials science $\mathcal{E}$ engineering. $R$, Reports : a Review Journal, Vol. 62, No. 4, (January 2008) pp. 125-155, ISSN 0927-796X

Conley, A.J.; Mohib, K.; Jevnikar, A.M. \& Brandle, J.E. (2009). Plant recombinant erythropoietin attenuates inflammatory kidney cell injury. Plant Biotechnology Journal, Vol. 7, No. 2, (November 2009), pp. 183-199, ISSN 14677644

Cowen, NM.; Smith, KA. \& Armstrong, K. (2007). Use of regulatory sequences in transgenic plants. Unitated States Patent, No. 7179902.

Cox, K.M.; Sterling, J.D.; Regan, J.T.; Gasdaska, J.R.; Frantz, K.K.; Peele, C.G.; Black, A.; Passmore, D.; Moldovan-Loomis, C.; Srinivasan, M.; Cuison, S.; Cardelli, P.M. \& Dickey, L.F. (2006). Glycan optimization of a human monoclonal antibody in the aquatic plant Lemna minor. Nature Biotechnology, Vol. 24, No. 11 (November 2006) pp. 1591-1597, ISSN 1087-0156

Cramer, CL.; Weissenborn, DL.; Oishi, KK.; Grabau, EA.; Benett S.; Ponce E.; Grabowski, GA. \& Radin, DN. (1996) Bioproduction of human enzymes in transgenic tobacco. 
Proceedings of the National Academy of Sciences of the United States of America, Vol. 729, No. 1, (May 1996), pp. 62-71, ISSN 0077-8923.

Cuatrecasas, P.; Wilchek, M. \& Anfinsen, C.B. (1968). Selective enzyme purification by affinity chromatography. Proceedings of the National Academy of Sciences, Vol. 61, No. 2, (October 1968) pp. 636-643, ISSN-0027-8424

Dai, Z.; Hooker, BS.; Anderson, DB. \& Thomas, SR. (2000). Improved plant based production of E1 endoglucanase using potato: expression. Mol Breeding, Vol. 6, No. 3, (June 2000), pp. 277-285, ISSN 1380-3743.

Daniell, H.; Streatfield, S.J. \& Wycoff K. (2001). Medical molecular farming: production of antibodies, biopharmaceuticals and edible vaccines in plants. Trends in Plant Science, Vol. 6, No. 5 (May 2001), pp. 219-226, ISSN 1360-1385

Decker, E.L. \& Reski, R. (2008). Current achievements in the production of complex biopharmaceuticals with moss bioreactors. Bioprocess Biosystems Engineering, Vol. 31, No. 1, (January 2008), pp. 3-9, ISSN 1615-76

Demain, A.L. \& Vaishnav, P. (2009). Production of recombinant proteins by microbes and higher organism. Biotechnology Advances, Vol. 27, No. 3, (June 2009), pp. 297-306, ISSN 0734-9750

De Muynck, B.; Navarre, C.; Nizet, Y.; Stadlmann, J. \& Boutry, M. (2009). Different subcellular localization and glycosylation for a functional antibody expressed in Nicotiana tabacum plants and suspension cells. Transgenic Research, Vol. 18, No. 3, (January 2009), pp. 467-482, ISSN 0962-8819

Fernández-San Millán, A.; Ortigosa, S.M.; Hervás-Stubbs, S.; Corral-Martínez, P.; SeguíSimarro, J.M.; Gaétan, J.; Coursaget, P. \& Veramendi, J. (2008) Human papillomavirus L1 protein expressed in tobacco chloroplasts self-assembles into virus-like particles that are highly immunogenic. Plant Biotechnology Journal, Vol. 6, No. 6, (April 2008), pp. 427-441, ISSN 14677644

Fischer, R. \& Emans, N. (2000). Molecular farming of pharmaceutical proteins. Transgenic Research, Vol. 9, No. 4-5. (August 2000), pp. 279-299, ISSN 1573-9368

Farran, I.; Sánchez-Serrano, J.J.; Medina, J.F.; Prieto, J. \& Mingo-Casel, A.M. (2002). Targeted expression of human serum albumin to potato tubers. Transgenic Research, Vol. 11, No. 4, (August 2002), pp. 337-346, ISSN 0962-8819

Floss, D.M.; Mockey, M.; Zanello, G.; Brosson, D.; Diogon, M.; Frutos, R.; Bruel, T.; Rodrigues, V.; Garzon, E.; Chevaleyre, C.; Berri, M.; Salmon, H.; Conrad, U. \& Dedieu, L. (2010). Expression and immunogenicity of the mycobacterial Ag85B/ESAT-6 antigens produced in transgenic plants by elastin-like peptide fusion strategy. Journal of Biomedicine Biotechnology, 2010:274346. Epub 2010 Apr 13, ISSN 1110-7243

Floss, D.M.; Sack, M.; Arcalis, E.; Stadlmann, J.; Quendler, H.; Rademacher, T.; Stoger, E.; Scheller, J.; Fischer, R. \& Conrad U. (2009). Influence of elastin-like peptide fusions on the quantity and quality of a tobacco-derived human immunodeficiency virusneutralizing antibody. Plant Biotechnology Journal, Vol. 7, No. 9, (December 2009), pp. 899-913, ISSN 1467-7644

Floss, D.M.; Sack, M.; Stadlmann, J.; Rademacher, T.; Scheller, J.; Stöger, E.; Fischer, R. \& Conrad, U. (2008). Biochemical and functional characterization of anti-HIV antibody-ELP fusion proteins from transgenic plants. Plant Biotechnology Journal, Vol. 6, No. 4, (May 2008), pp. 379-391, ISSN 1467-7644 
Floss, D.M.; Schallau, K.; Rose-John, S.; Conrad, U. \& Scheller, J. (2010). Elastin-like polypeptides revolutionize recombinant protein expression and their biomedical application. Trends in Biotechnology, Vol. 28, No. 1, (January 2010), pp. 37-45, ISSN 0167-7799

Fogher, C. (2000). A synthetic polynucleotide coding for human lactoferrin, vectors, cells and transgenic plants containing it. Gene bank acc no AX006477, Patent: W00004146.

Fong, BA.; Wu, WY.; \& Wood, DW. (2010). The potential role of self-cleaving purification tags in commercial-scale processes. Trends in Biotechnology, Vol. 28, No. 5, (May 2010) pp. 272-279, ISSN 0167-7799

Franconi, R.; Demurtas, OC. \& Massa, S. (2010). Plant derived vaccines and other therapeutics produced in contained systems. Expert Review of Vaccines, Vol. 9, No. 8, (October 2010), pp. 877-892, ISSN 1476-0584.

Fujiwara, Y.; Aiki, Y.; Yang, L.; Takaiwa, F.; Kosaka, A.; Tsuji, N.M.; Shiraki, K. \& Sekikawa, K. (2010). Extraction and purification of human interleukin-10 from transgenic rice seeds. Protein Expression and Purification, Vol. 72, No. 1, (February 2010), pp. 125130, ISSN 1046-5928

Ge, X. \& Filipe, C.D. (2006) Simultaneous phase transition of ELP tagged molecules and free ELP: an efficient and reversible capture system. Biomacromolecules, Vol. 7, No. 9, (Septrember 2006), pp. 2475-2478, ISSN 1525-7797

Ge, X.; Trabbic-Carlson, K.; Chilkoti, A. \& Filipe, C.D.M. (2006). Purification of an elastinlike fusion protein by microfiltration. Biotechnology and Bioengineering, Vol. 95, No. 3, (October 2006), pp. 424-32 46-851, ISSN 0006-3592

Girard, L.S.; Fabis, M.J.; Bastin, M.; Courtois, D.; Pétiard, V. \& Koprowski, H. (2006). Expression of a human anti-rabies virus monoclonal antibody in tobacco cell culture. Biochemical and Biophysical Research Communications, Vol. 345, No. 2, (January 2006) pp. 602-607, ISSN 0006-291X

Gleba, Y.; Klimyuk, V. \& Marillonnet S. (2005). Magnifection - a new platform for expressing recombinant vaccines in plants. Vaccine, Vol. 23, No. 17-18, (March 2005), pp. 2042-2048, ISSN 0264-410X.

Gómeza, E.; Zotha, S.Ch.; Asurmendia, S.; Vázquez Roverea, C. \& Berinstein, A. (2009). Expression of Hemagglutinin-Neuraminidase glycoprotein of Newcastle Disease Virus in agroinfiltrated Nicotiana benthamiana plants. Journal of Biotechnology, Vol. 144 , No. 4, (September 2009), pp. 337-340, ISSN 0168-1656

Gomord, V. \& Faye L. (2004). Posttranslational modification of therapeutic proteins in plants. Current Opinion in Plant Biology, Vol. 7, No. 2, (April 2004), pp. 171-181, ISSN 1369-5266

Halweg, C.; Thompson, WF. \& Spiker, S. (2005). The rb7 matrix attachment region increase the likehood and magnitude of transgene expression in tobacco cells: a flow cytometric study. Plant Cell, Vol. 17, No. 2, (February 2005), pp. 418-429, ISSN 1040-4651.

Hearn, M.T. \& Acosta, D. (2001). Applications of novel affinity cassette methods: use of peptide fusion handles for the purification of recombinant proteins. Journal of Molecular Recognition, Vol. 14, No. 6, (December 2001), pp. 323-369, ISSN 0952-3499

Hellwig, S.; Drossard, J.; Twyman, RM. \& Fischer R. (2004). Plant cell cultures for the production of recombinant proteins. Nature Biotechnology, Vol. 22 No. 11, (November 2004), pp. 1415-1422, ISSN 1087-0156. 
Herman, SR.; Harding, RM. \& Dale, JL. (2001). The banana actin 1 promoter drives near constitutive transgene expression in vegetative tissue of banana (Musa spp.). Plant Cell Report, Vol. 20, No. 6, (July 2001), pp. 525-530, ISSN 0721-7714.

Hiatt, A.; Cafferkey, R. \& Bowdish, K. (1989). Production of antibodies in transgenic plants. Nature, Vol. 342, No. 6245, (July-August 1989), pp. 76-78, ISSN 0028-0836

Huang, Z.; Santi, L.; LePore, K.; Kilbourne, J.; Arntzen, CJ. \& Mason HS. (2006). Rapid, high level production of hepatitis B core antigen in plant leaf and its immunogenicity in mice. Vaccine, Vol. 24, No. 14, (December 2006), pp. 2506-2513, ISSN 0264-410X.

Hull, AK.; Criscuolo, CJ.; Mett, V.; Groen, H.; Steeman, W.; Westra, H.; Chapman, G.; Legutki, B.; Baillie, L. \& Yusibov, V. (2005). Human-derived, plant-produced monoclonal antibody for the treatment of anthrax. Vaccine, Vol. 23, No. 17-18, (March 2005), pp. 2082-2086 , ISSN 0264-410X

Jeferson, R.; Goldsbrough, A. \& Bevan, M. (1990). Transcriptional regulation of a patatin-1 gene in potato. Plant Molecular Biology, Vol. 14, No. 6, (February 1990), pp. 995-1006, ISSN 0735-9640.

Jiang, XL.; He, ZM.; Peng, ZQ.; Qi, Y.; Chen, Q \& You, SY. (2007). Cholera toxin B protein in transgenic tomato fruit induces systemic immune response in mice. Trangenic Research, Vol. 16. No. 2, (April 2007), pp. 169-175, ISSN 1573-9368

Joensuu, J.J.; Brown, K.D.; Conley, A.J.; Clavijo, A.; Menassa, R. \& Brandle, J.E. (2009) Expression and purification of an anti-Foot-and-mouth disease virus single chain variable antibody fragment in tobacco plants. Transgenic Research, Vol. 18, No. 5, (October 2009), pp. 685-696, ISSN 0962-8819

Kabir, M.E.; Krishnaswamy, S.; Miyamoto, M.; Furuichi, Y. \& Komiyama, T. (2010). Purification and functional characterization of a Camelid-like single-domain antimycotic antibody by engineering in affinity tag. Protein Expression and Purification, Vol. 72, No. 1, (July 2010), pp. 59-65, ISSN 1046-5928

Kaiser, J. (2008). Is the drought over for pharming? Science, Vol. 320, No. 5875, (April 2008), pp. 473-475, ISSN 1095-9203

Kalbina, I.; Engstrand, L.; Andersson, S. \& Strid, A. (2010).Expression of Helicobacter pylori TonB Protein in Transgenic Arabidopsis thaliana: Toward Production of Vaccine Antigens in Plants. Helicobacter, Vol. 15, No. 5, (October 2010), pp. 430-437, ISSN 1523-5378

Khalsa, G.; Mason, HS. \& Arntzen CJ. (2004). Plant derived vaccines: progress and constrains, In: Molecular farming: plant made pharmaceuticals and technical proteins, $\mathrm{R}$. Fischer, S. Schillberg, (Ed), pp. 135-158, Wiley-VCH, ISBN 9783527603633, Weinheim, Germany.

Kim, J.Y.; Mulchandani, A. \& Chen, W. (2004). Temperature-triggered purification of antibodies. Biotechnology and Bioengineering, Vol. 90, No. 3, (May 2004), pp. 373-379, ISSN 0006-3592

Ko, K.; Tekoah, Y.; Rudd, PM.; Harvey, DJ.; Dwek, RA.; Spitsin, S.; Hanlon, CA.; Rupprecht, C.; Dietzschold, B.; Golovkin, M. \& Koprowski, H. (2003). Function and glycosylation of plant-derived antiviral monoclonal antibody. Proceedings of the National Academy of Sciences of the United States of America, Vol. 100, No. 13, (June 2003), pp. 8013-8018, ISSN 0027-8424 
Komarova, TV.; Baschieri, S.; Donini, M.; Marusic, C.; Benvenuto, E. \& Dorokhov YL. (2010). Transient expression system for plant derived biopharmaceuticals. Expert Review of Vaccines, Vol. 9, No. 8, (October 2009), pp. 859-876, ISSN 1476-0584.

Lentz, EM.; Segretin, M.E.; Mauro M.; Wirth, SA.; Mozgovoj, MV.; Wigdorovitz, A. \& BravoAlmonacid, F.F. (2010). High expression level of a foot and mouth disease virus epitope in tobacco transplastomic plants. Planta, Vol. 231, No. 2, (November 2010), pp. 387-395, ISSN 0032-0935

Lichty, JJ.; Malecki, JL.; Agnew, HD.; Michelson-Horowitz, DJ. \& Tan, S. (2005). Comparison of affnity tags for protein purifcation. Protein Expression and Purification, Vol. 41, No. 1, (May 2005), pp. 98-105, ISSN 1046-5928

Lin, M.; Rose-John, S.; Grötzinger, J.; Conrad, U. \& Scheller. J. (2006). Functional expression of a biologically active fragment of soluble gp130 as an ELP-fusion protein in transgenic plants: purification via inverse transition cycling. The Biochemical Journal, Vol. 398, No. 3, (September 2006), pp. 577-583, ISSN 0264-6021

Ling, HY.; Pelosi, A. \& Walmsley, AM. (2010). Current status of plant made vaccines for veterinary purposes. Expert Review of Vaccines, Vol. 9, No. 8, (October 2009), pp. 971-982, ISSN 1476-0584

Mackay, J.A. \& Chilkoti, A. (2008). Temperature sensitive peptides: engineering hyperthermia-directed therapeutics. International Journal of Hyperthermia : the Official Journal of European Society for Hyperthermic Oncology, North American Hyperthermia Group, Vol. 24, No. 6, (September 2008), pp. 846-851, ISSN 0265-6736

Makvandi-Nejad, S.; McLean, M.D.; Hirama,T.; Almquist, K.C.; Mackenzie, C.R. \& Hall, J.C. (2005). Transgenic tobacco plants expressing a dimeric single-chain variable fragment (scfv) antibody against Salmonella enterica serotype Paratyphi B. Transgenic Research, Vol. 14, No. 5, (October 2005), pp. 785-792, ISSN 0962-8819

Marcondes, J. \& Hansen, E. (2008).Transgenic Lettuce Seedlings Carrying Hepatitis B Virus Antigen HBsAg Brazilian Journal of Infectious Diseases, Vol. 12, No. 6, (December 2008), pp. 469-471, ISSN 1413-8670

Medrano, G.; Reidy, MJ.; Liu J.; Ayala, J.; Dolan, M.C. \& Cramer CL. (2009). Rapid system for evaluating bioproduction capa city complex pharmaceutical proteins in plants. Method in Molecular Biology, Vol. 483, (January 2008), pp. 51-67, ISSN 1064-3745.

Menassa, R.; Zhu, H.; Karatzs, CN.; Lazaris, A.; Richman, A. \& Brandle J. (2004). Spider dragline silk proteins in transgenic tobacco leaves: accumulation and field production. Plant Biotechnol Journal, Vol. 2, No 5. (September 2004), pp. 431-438, ISSN 1229-2818.

Meyer, D.E. \& Chilkoti, A. (1999). Purification of recombinant proteins by fusion with thermally-responsive polypeptides. Nature Biotechnology. Vol. 17, No.11, (January 1999) pp. 1112-1115, ISSN 1087-0156

Meyer, D.E. \& Chilkoti, A. (2004). Quantification of the effect of chain length and concentration on the thermal behavior of elastin-like polypeptides. Biomacromolecules, Vol. 5, No. 3, (May - June 2004), pp. 846-851, ISSN 1525-7797

Mithieux, S.M. \& Weiss, A.S. (2005). Elastin. Advances in Protein Chemistry, Vol. 70, pp. 437461, ISSN 0065-3233

Muto, M.; Ryan, HE. \& Mayfield, SP. ( 2009). Accumulation and processing of a recombinant protein designed as a cleavable fusion to the endogenous Rubisco LSU protein in 
Chlamydomonas chloroplast. BMC Biotechnology, Vol. 9, (March 2009), pp. 26, doi:10.1186/1472-6750-9-26, ISSN 1472-6750

Ohana, R.,F.; Encell, L.P.; Zhao, K.; Simpson D.; Slater, M.R.; Urh, M.; \& Wood, K.V. (2009). HaloTag7: A genetically engineered tag that enhances bacterial expression of soluble proteins and improves protein purification. Protein Expression and Purification, Vol. 68, No. 1, (November 2009), pp. 110-120, ISSN 1046-5928

Osborn, TC.; Burrow, M. \& Bliss, FA. (1988). Purification and characterization of arcelin seed protein from common bean. Plant Physiology, Vol. 86, No. 2, (February 1988), pp. 399-405, ISSN 2345476478

Patel, J.; Zhu, H.; Menassa, R.; Gyenis, L.; Richman, A. \& Brandle, J. (2007). Elastin-like polypeptide fusions enhance the accumulation of recombinant proteins in tobacco leaves. Transgenic Research, Vol. 16, No. 2, (April 2007) pp. 239-249, ISSN 0962-8819

Rabindran, S.; Roy, N.; Fedorkin, G. \& Skarjinskaia, M. (2009). Plant-Produced Human Growth Hormone Shows Biological Activity in a Rat Model. Biotechnology Progress, Vol. 25, No. 2, (March 2009), pp. 530-534, ISSN 1520-6033

Rival, S.; Wisniewski, JP.; Langlais, A.; Kaplan, H.; Freyssinet, G.; Vancanneyt , G.; Vunsh, R.; Perl, A. \& Edelman M. (2008). Spirodela (duckweed) as an alternative production system for pharmaceuticals: a case study, aprotinin. Transgenic Research, Vol. 17, No. 4, (August 2008), pp. 503-513, ISSN 0962-8819

Rodríguez, M.; Ramírez, NI.; Ayala, M.; Freyre, F.; Pérez, L.; Triguero, A.; Mateo, C.; Selman-Housein, G.; Gavilondo, JV. \& Pujol, M. (2005). Transient expression in tobacco leaves of an aglycosylated recombinant antibody against the epidermal growth factor receptor. Biotechnology and Bioengineering, Vol. 89, No. 2, (January 2005), pp. 188-194, ISSN 0006-3592

Rodriguez-Cabello, J.C.; Prieto, S.; Reguera, J.; Arias, F.J. \& Ribeiro, A. (2007). Biofunctional design of elastin-like polymers for advanced aplications in nanobiotechnology. Journal of Biomaterials Science. Polymer Edition, Vol. 18, No. 3, (March 2007), pp. 269286, ISSN 0920-5063

Rojas-Anaya, E.; Loza-Rubio, E.; Olivera-Flores, M.T. \& Gomez-Lim, M. (2009). Expression of rabies virus $G$ protein in carrots (Daucus carota) Transgenic Research, Vol. 18, No. 6, (December 2009), pp.911-919, ISSN 0962-8819

Sack, M.; Paetz, A.; Kunert, R.; Bomble, M.; Hesse, F.; Stiegler, G.; Fischer, R.; Katinger, H.; Stoeger, E. \& Rademacher, T. (2007). Functional analysis of the broadly neutralizing human anti-HIV-1 antibody 2F5 produced in transgenic BY-2 suspension cultures. he FASEB journal : official publication of the Federation of American Societies for Experimental Biology, Vol. 21, No. 8, (June 2007) pp. 1655-1664, ISSN 0892-6638

Scheller, J.; Hengger, D.; Viviani, A. \& Conrad, U. (2004). Purification of spider silk elastin from transgenic plants and application for human chondrocyte proliferation. Transgenic Research, Vol. 13, No. 1, (February 2004) pp. 51-57, ISSN 1573-9368.

Serrano, V.; Liu, W. \& Franzen, S. (2007). An infrared spectroscopic study of the conformational transition of elastin-like polypeptides. Biophysical Journal, Vol. 93, No. 7, (October 2007), pp. 2429-2435, ISSN 0006-3495

Sharma, AK. \& Sharma, MK. (2009). Plants as bioreactors: Recent developments and emerging opportunities. Biotechnology Advances, Vol. 27, No. 6, (June 2009), pp. 811832, ISSN 1476-0584. 
Sharma, M. \& Sood, B. (2011). A banana or syringe: journey to edible vaccines. World Journal of Microbiology and Biotechnology, Vol. 27, No. 3, (June 2011), pp. 471-477, ISSN 1573-0972

Shoji, Y.; Chichester, JA.; Jones, M.; Manceva, SD.; Damon, E.; Mett, V.; Musiychuk, KB.; H. Farrance, Ch.; Shamloul, M.; Kushnir, N.; Sharma S. \& Vidadi YV. (2011) Plantbased rapid production of recombinant subunit hemagglutinin vaccines targeting H1N1 and H5N1 influenza. Human Vaccines, Vol. 7, Supplement, (January/February 2011), pp. 41-50, ISSN 1554-8600

Smith, ML.; Mason, HS. \& Shuler, ML. (2002). Hepatis B surface antigen (HBsAg) expression in plant cell culture: kinetics of antigen accumulation in batch culture and its intracellular form. Biotechnology Bioengineering, Vol. 80, No. 7, (December 2002), pp. 812-822, ISSN 0006-3592.

Steen, J.; Uhlén, M.; Hober, S. \& Ottosson, J. (2006). High-throughput protein purification using an automated set-up for high-yield affinity chromatography. Protein Expression and Purification, Vol. 46, No. 2, pp. 173-178, ISSN 1046-5928

Stefanov, I.; Illubaev, S.; Feher, A.; Margoczi, K. \& Dudits D. (1991). Promoter and genotype dependent transient expression of a reporter gene in plant protoplasts. Acta Biologica Hungarica, Vol. 42, No. 4, (April 1991), pp. 323-330, ISSN 0236-5383.

Stefanova, G.; Vlahlova, M. \& Atanassov A. (2008). Production of recombinant human lactoferrin from transgenic plants. Biology Plantarum, Vol. 52, No. 3, (May 2008), pp. 423-428, ISSN 1573-8264

Stevens, LH.; Stoopen, GM.; Elbers, IJ.; Molthoff, JW.; Bakker, HA.; Lommen, A.; Bosch, D. \& Jordi, W. (2000). Effect of climate conditions and plant developmental stage on the stability of antibodies expressed in transgenic tobacco. Plant Physiology, Vol. 124, No. 1, ( May 2000), pp. 173-182, ISSN 0032-0889

Stoger, E .; Sack , M.; Perrin, Y.; Vaquero, C.; Torres, E.; Twyman, RM.; Christou, P. \& Fischer, R. (2002) Practical considerations for pharmaceutical antibody production in different crop systems. Molecular Breeding, Vol. 9, No. 3, (September 2002), pp. 149 - 158, ISSN 1380-3743

Streatfield, SJ. (2006). Mucosal immunization using recombinant plant based oral vaccines. Methods, Vol. 38, No. 2, (February 2006), pp. 150-157, ISSN 1046-2023.

Tacket, CO. (2005). Plant derived vaccines against diarrheal diseases. Vaccine, Vol. 23, No. 15, (March 2005), pp. 1866-1869, ISSN 0264-410X.

Thanavala, Y.; Huang, Z. \& Mason, HS. (2006). Plant derived vaccines: a look back at the highlights and a view to the challenges on the road ahead. Expert Review of Vaccines, Vol. 5, No. 2, (February 2006), pp. 249-260, ISSN 1476-0584

Trabbic-Carlson, K.; Meyer, DE.; Liu, L.; Piervincenzi, R.; Nath, N.; LaBean, T. \& Chilkoti, A. (2004) Effect of protein fusion on the transition temperature of an environmentally responsive elastin-like polypeptide: a role for surface hydrophobicity? Protein Engineering Design and Selection, Vol. 17, No. 1, (August 2004), pp. 57-66, ISSN 17410126

Valdez-Ortiz, A.; Rascón-Cruz, Q.; Medina-Godoy, S.; Sinagawa-García, S.R.; ValverdeGonzález, M.E. \& Paredes-López, O. (2005). One-step purification and structural characterization of a recombinant His-tag $11 S$ globulin expressed in transgenic tobacco. Journal of Biotechnology, Vol. 115, No. 4, (February 2005), pp. 413-423, ISSN 0168-1656 
Valiaev, A.; Lim, DW.; Schmidler, S.; Clark, RL.; Chilkoti, A. \& Zauscher, S. (2008). Hydration and conformational mechanics of single, end-tethered elastin-like polypeptides. Journal of the American Chemical Society, Vol. 130, No. 33, (July 2008), pp. 10939-10946, ISSN 0002-7863

Vaquero, C.; Sack, M.; Schuster, F.; Finnern, R.; Drossard, J.; Schumann, D.; Reimann, A.; \& Fischer, R. (2002). A carcinoembryonic antigen-specific diabody produced in tobacco. The FASEB Journal: Official Publication of the Federation of American Societies for Experimental Biology, Vol. 16, No. 3, (January 2002), pp. 408-410, ISSN 0892-6638

Villani, M.E.; Morgun, B.; Brunetti, P.; Marusic, C.; Lombardi, R.; Pisoni, I.; Bacci, C.; Desiderio, A.; Benvenuto, E. \& Donini, M. (2009). Plant pharming of a full-sized, tumour-targeting antibody using different expression strategies. Plant Biotechnology Journal, Vol. 7, No. 1, (January 2009), pp. 59-72, ISSN 1467-7644

Waugh, DS. (2005). Making the most of affinity tags. Trends in Biotechnology, Vol. 23, No. 6, (June 2005), pp. 316-320, ISSN 0167-7799

Webster, DE.; Wang, L.; Mulcair, M.; Ma, Ch.; Santi, L.; Mason, HS.; Wesselingh, S.L.; Ross L. \& Coppel, R.L. (2009). Production and characterization of an orally immunogenic Plasmodium antigen in plants using a virus-based expression system. Plant Biotechnology Journal Vol. 7, No. 9, (December 2009), pp. 846-855, ISSN 14677644

Wiktorek-Smagur, A.; Hnatuszko-Konka, K.; Gerszberg, A.; Łuchniak, P.; Kowalczyk, T. \& Kononowicz, AK. (2011). Expression of a staphylokinase, a thrombolytic agent in Arabidopsis thaliana. World Journal Microbiology and Biotechnology, Vol. 27, No. 6, (June 2011), pp. 1341-1347, ISSN 0959-3993

Witte, CP.; Noël, L.D.; Gielbert, J.; Parker, J.E. \& Romeis, T. (2004). Rapid one-step protein purification from plant material using the eight-amino acid StrepII epitope. Plant Molecular Biology, Vol. 55, No. 1, (May 2004), pp. 135-147, ISSN 0167-4412

Wu, Cy.; Suzuki, A.; Washida, H. \& Takaiwa, F. (1988). The GCN4 motif in a rice glutelin gene is essential for endosperm specific gene expression and is activated by Opaquae-2 in transgenic rice plants. Plant Journal, Vol. 14, No. 6, (June 1988), pp. 673-683, ISSN 1365-313X.

Xie, Y.; Liu, Y.; Meng, M.; Chen, L. \& Zhu, Z. (2003). Isolation and identification of a super strong plant promoter from cotton leaf curl Multan virus. Plant Molecular Biology Vol. 53, No. 1-2, (July 2003), pp. 1-14, ISSN 0735-9640.

Xu, J.; Ge, X. \& Dolan MC. (2011). Towards high-yield production of pharmaceuticals proteins with plant cell suspension culture. Biotechnology Advances, Vol. 29, No. 3, (January 2011), pp. 278-299, ISSN 0734-9750.

Yano, A.; Maeda, F. \& Takekoshi M. (2004). Transgenic tobacco cells producing the human monoclonal antibody to hepatitis B virus surface antigen. Journal of Medical Virology, Vol. 73, No. 2, (June 2004), pp. 208-215 , ISSN 0146-6615

Yap, YK. \& Smith DR. (2010). Strategies for the plant based expression of dengue subunit vaccines. Biotechnology and Applied Biochemistry, Vol. 57, No. 2, (December 2010), pp. 47-53, ISSN 0885-4513.

Yarmush, M.L.; Toner, M.; Plonsey, R. \& Bronzino J.D. (2003). Monoclonal Antibodies and Their Engineered Fragments In: Biotechnology for Biomedical Engineers, 1-17, CRC Press; 1 edition (March 26, 2003), ISBN 0-8493-1811-4 
Yu, J. \& Langridge, W. (2003). Expression of rotavirus capsid protein VP6 in transgenic potato and its oral immunogenicity in mice. Transgenic Research, Vol. 12, No. 2, (April 2003), pp. 163-169, ISSN 1573-9368

Yusibov, V. \& Rabindran, S. (2008). Recent progress in the development of plant derived vaccines. Expert Review of Vaccines, Vol. 7, No. 8, (October 2008), pp. 1173-1183, ISSN 1476-0584.

Zhang, D.; Nandi, S.; Bryan, P.; Pettit, S.; Nguyen, D.; Santos, MA. \& Huang, N. (2010). Expression, purification, and characterization of recombinant human transferrin from rice (Oryza sativa L.). Protein Expression and Purification, Vol. 74, No. 1, (November 2010), pp. 69-70, ISSN 1046-5928

Zhou, A. \& Li, J. (2005). Arabidopsis BRS1 is a secreted and active serine carboxypeptidase. The Journal of Biological Chemistry, Vol. 280, No. 42, (October 2005), pp. 35554355561, ISSN 0021-9258

Zuo, J. \& Chua, NH. (2000). Chemical-inducible systems for regulated expression of plant genes. Current Opinion in Biotechnology, Vol. 11, No. 2, (April 2000), pp. 146-151, ISSN 0958-1669. 


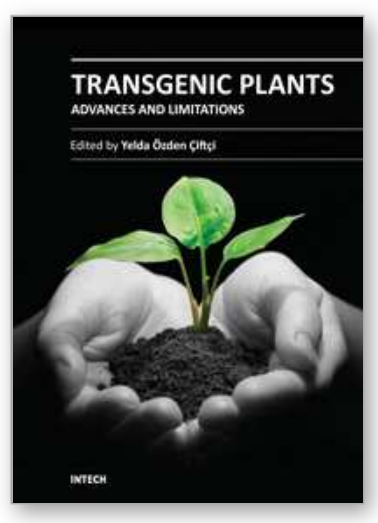

\author{
Transgenic Plants - Advances and Limitations \\ Edited by PhD. Yelda Ozden Çiftçi
}

ISBN 978-953-51-0181-9

Hard cover, 478 pages

Publisher InTech

Published online 07, March, 2012

Published in print edition March, 2012

Development of efficient transformation protocols is becoming a complementary strategy to conventional breeding techniques for the improvement of crops. Thus, Transgenic Plants - Advances and Limitations covers the recent advances carried on improvement of transformation methods together with assessment of the impact of genetically transformed crops on biosafety. Each chapter has been written by one or more experienced researchers in the field and then carefully edited to ensure throughness and consistency.

\title{
How to reference
}

In order to correctly reference this scholarly work, feel free to copy and paste the following:

Aneta Wiktorek-Smagur, Katarzyna Hnatuszko-Konka, Aneta Gerszberg, Tomasz Kowalczyk, Piotr Luchniak and Andrzej K. Kononowicz (2012). Green Way of Biomedicine - How to Force Plants to Produce New Important Proteins, Transgenic Plants - Advances and Limitations, PhD. Yelda Ozden Çiftçi (Ed.), ISBN: 978953-51-0181-9, InTech, Available from: http://www.intechopen.com/books/transgenic-plants-advances-andlimitations/green-way-of-biomedicine-how-to-force-plants-to-produce-new-important-proteins

\section{INTECH}

open science | open minds

\section{InTech Europe}

University Campus STeP Ri

Slavka Krautzeka 83/A

51000 Rijeka, Croatia

Phone: +385 (51) 770447

Fax: +385 (51) 686166

www.intechopen.com

\section{InTech China}

Unit 405, Office Block, Hotel Equatorial Shanghai

No.65, Yan An Road (West), Shanghai, 200040, China

中国上海市延安西路65号上海国际贵都大饭店办公楼 405 单元

Phone: +86-21-62489820

Fax: +86-21-62489821 